\title{
Active tectonics and first paleoseismological results in Faial, Pico and S. Jorge islands (Azores, Portugal)
}

\author{
José Madeira and António Brum da Silveira \\ Departamento de Geologia and Laboratório de Tectonofísica e Tectónica Experimental, \\ Faculdade de Ciências da Universidade de Lisboa, Portugal
}

\begin{abstract}
The neotectonics of the islands of Faial, Pico and S. Jorge (Azores) is presented. Preliminary paleoseismology data from trench exposures across three active fault zones (Lomba do Meio, Lagoa do Capitão and Pico do Carvão faults) complement the information. Radiocarbon age constraints of paleoearthquakes suggest clustering of surface rupturing events. Slip rates deduced from paleoseismology analysis range from 0.10 to $0.40 \mathrm{~cm} / \mathrm{year}$ and validate long-term slip rates obtained by neotectonic studies (using Pleistocene markers). The studied faults allowed a preliminary seismic hazard assessment: magnitudes of the largest paleoearthquakes, determined from slip per event range from $M_{w}=6.9$ to 7.1, and maximum expected magnitudes, estimated from rupture length or rupture area, vary from $M_{w}=6.4$ to 6.8. The former $M_{w}$ estimates are in closer agreement with the magnitude of the major historic and instrumental seismic events in the archipelago, even though the used empirical relations between magnitude and rupture parameters may not be the most adequate due to the unique tectonic setting of Azores.
\end{abstract}

Key words Azores - neotectonics - active faulting paleoseismology - seismic hazard

\section{Introduction}

The studied region is located in a unique tectonic setting (fig. 1). The central and eastern groups of the Azores islands stand on a broad sheared region that absorbs the deformation induced by the eastward differential displacement of the Eurasian and African plates, east of the Azores triple junction. The volcanism that built the islands and submarine volcanoes is tectonically controlled and is a result of the

Mailing address: Dr. José Madeira, Departamento de Geologia and Laboratório de Tectonofísica e Tectónica Experimental, Faculdade de Ciências da Universidade de Lisboa, Edifício C2, $5^{\circ}$ piso, Campo Grande, 1749-016 Lisboa, Portugal; e-mail: jmadeira@fc.ul.pt transtensile regime acting on that portion of oceanic lithosphere. The deformation is represented by widespread active faulting of the islands and the surrounding seafloor.

This work presents the description of the tectonic structure of three islands from the Azores central group: Faial, Pico and S. Jorge. The faults were mapped through fieldwork and vertical airphoto interpretation. Kinematics was deduced from rare striated fault surfaces and displaced stratigraphic and morphological markers. Determination of fault separations of K/Ar dated volcanostratigraphic units (at the scale of the island) by cartographic methods allowed the estimation of slip rates for a time scale of the order of tens or hundreds of thousand years.

In order to verify the validity of the obtained slip rate values, and to observe the faults at different time and geometry scales, exploratory paleoseismology studies were performed across three known active faults, one from each island. The 


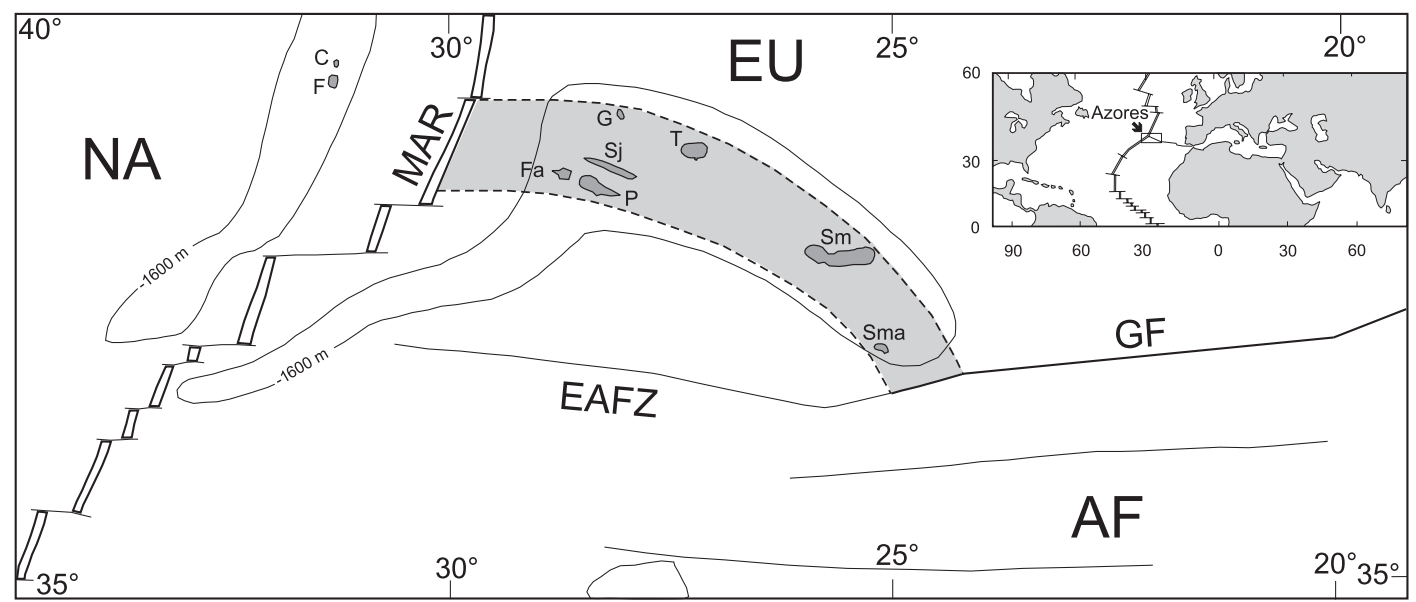

Fig. 1. Tectonic setting of the Azores archipelago (modified from Laughton and Whitmarsh, 1974; Lourenço et al., 1998; Madeira, 1998). The Mid Atlantic Ridge (MAR) separates the North American plate (NA) from Eurasia (EU) and Africa (AF). The Azores Oblique Spreading Centre (grey area) and Gloria Fault (GF) separate Eurasia from Africa. The East Azores Fault Zone (EAFZ) is an abandoned segment of the Eurasia-Africa boundary. The archipelago islands are Corvo (C), Flores (F), Graciosa (G), Terceira (T), S. Jorge ( $\mathrm{Sj}$ ), Faial (Fa), Pico (P), S. Miguel (Sm) and Santa Maria (Sma). The Azores Plateau is enclosed by the $1600 \mathrm{~m}$ isobath (thin line). Inset shows location of archipelago in the Atlantic and its relation with the mid-Atlantic ridge and the Azores-Gibraltar boundary.

paleoseismological analysis was to complement the neotectonic study of the three islands and, therefore, must be understood as a preliminary and exploratory work. The choice of the trenched faults and their location depends on geological and morphological reasons, including: the size of the fault scarps (many of the main faults present scarps several tens to hundreds of metres high with the base covered by thick talus deposits); their topographic position (scarps located in depressed areas are unfavourable as they are either partially fossilized by recent deposits or amplified by stream erosion); morphologically fresh aspect of scarps suggesting recent surface rupture and/or knowledge of historic surface rupturing events; nature of the materials exposed in the scarps (where possible, scarps cut in pyroclastic deposits were preferred to those that expose the lava flow basement).

Paleoseismology results allowed the determination of age of paleoearthquakes, estimation of recurrence intervals, and comparison of slip rates for different time scales.

\section{Geological setting}

The Azores archipelago is located at the North America, Eurasia and Africa triple junction (fig. 1). The Mid Atlantic Ridge separates the American from the Eurasian and African plates; east of the rift, the Azores-Gibraltar Fault Zone is the boundary between Eurasia and Africa.

The islands of Flores and Corvo lie on the American plate, while the central (Graciosa, Terceira, S. Jorge, Faial and Pico) and eastern (S. Miguel, Santa Maria and Formigas islets) groups of islands are located along the western segment of the Azores-Gibraltar Fault Zone (Madeira, 1998; Lourenço et al., 1998), whose morphologic expression is the Azores Plateau. The region is under right lateral transtension as a result of higher rates of spreading north of the triple point and to the obliquity of the Azorean segment of the Eurasian-African plate boundary relatively to the spreading direction. 
Table I. Historic tectonic seismicity in Azores.

\begin{tabular}{|c|c|c|c|c|}
\hline Date & Location & $\begin{array}{l}\text { Intensity } \\
\text { (MCS-17; } \\
\text { MM-56) }\end{array}$ & $\begin{array}{l}\text { Estimated } \\
\text { magnitude }\end{array}$ & Effects of earthquake \\
\hline Oct. 22,1522 & S. Miguel & $X\left(^{1}\right)$ & & $\begin{array}{l}\text { Voluminous landslides; } \\
\text { > } 5000 \text { deaths estimated }\end{array}$ \\
\hline June-July, 1571 & $\begin{array}{l}\text { D. João de } \\
\text { Castro Bank }\end{array}$ & VI/VII & & Seismic swarm \\
\hline May 24,1614 & Terceira & X/XI; VIII $\left({ }^{2}\right)$ & $>6.3$ & $\begin{array}{l}>8 \mathrm{~km} \text { of surface rupture } \\
\text { on Lajes Fault; } 93 \text { deaths }\left({ }^{3}\right)\end{array}$ \\
\hline June 9, 1647 & Terceira & $\mathrm{V} / \mathrm{VI}$ & & \\
\hline Oct. 19,1656 & S. Miguel & IV/V & & \\
\hline March 29, 1690 & Central Group & $\mathrm{V}$ & & Alternative date is April 5, 1690 \\
\hline Nov. $15-25,1698$ & Terceira & IV & & Seismic swarm \\
\hline Dec. 8,1713 & S. Miguel & VI/VII & & \\
\hline July 9,1757 & S. Jorge & $\mathrm{X} / \mathrm{XI}$ & $7.1 ; 7.4\left({ }^{4}\right)$ & $\begin{array}{c}\text { Deaths: } 1034 \text { in S. Jorge; } \\
11 \text { in Pico; small tsunami observed }\end{array}$ \\
\hline Dec. 1759 to May 1760 & Faial & VI & & Seismic swarm \\
\hline Aug. 1791 & Terceira & $\mathrm{IV} / \mathrm{V}$ & & \\
\hline Jan. 21, 1837 & Graciosa & VIII; IX $\left(^{2}\right)$ & & $\begin{array}{l}\text { Probable rupture in Serra das } \\
\text { Fontes Fault; } 3 \text { deaths }\end{array}$ \\
\hline June 15,1841 & Terceira & $\mathrm{X} / \mathrm{XI} ; \mathrm{IX}\left({ }^{2}\right)$ & & $\begin{array}{l}>1 \mathrm{~km} \text { of surface rupture in Cruz } \\
\text { do Marco Fault; } 5500 \text { homeless }\end{array}$ \\
\hline Oct. 30 to Nov. 8,1848 & S. Miguel & VI/VII & & Seismic swarm \\
\hline April 16, 1852 & S. Miguel & VII/VIII; VI ( $\left.{ }^{2}\right)$ & & 9 deaths \\
\hline Sept. 21 to Dec. 10, 1862 & Faial & $\mathrm{V} / \mathrm{VI}$ & & Seismic swarm \\
\hline March 16, 1920 & Faial & $\mathrm{V}$ & & \\
\hline Feb. 9, 1924 & Faial & $\mathrm{V} / \mathrm{VI}$ & & \\
\hline Aug. 31, 1926 & Faial & VIII/IX; X $\left(^{2}\right)$ & & 8 deaths \\
\hline
\end{tabular}

$\left({ }^{1}\right)$ Machado (1966); $\left({ }^{2}\right)$ Nunes (1991); Nunes et al., (1992); $\left({ }^{3}\right)$ coeval texts refer three different numbers: 29, 93 or $>200$ deaths; 93 is the most credible number; $\left(^{4}\right)$ Machado, (1949).

As a result of its location on an active plate boundary, the archipelago is subject to frequent seismic activity. Although most are low to moderate magnitude seismic isolated events or swarms, the islands are occasionally struck by high magnitude $(M \sim 7)$ earthquakes (table $\mathrm{I}$; fig. 2) exemplified by the October 22nd, 1522, S. Miguel earthquake ( 5000 victims $)$, the July 9th, 1757, S. Jorge event ( 1000 deaths) and the January 1st, 1980, Terceira earthquake (64 casualties) (McKenzie, 1972; Udías et al., 1976, 1986; Hirn et al., 1980; Udías, 1980; Grimison and Chen, 1986; Buforn et al., 1988; Moreira, 1991; Mezcua et al., 1991; Nunes et al., 1992;
Miranda et al., 1998). Published focal mechanisms (table II; fig. 2) indicate dominant normal, dextral and sinistral strike-slip solutions on WNW-ESE and NNW-SSE structures.

Volcanism has also been observed since the settlement of the archipelago in mid 14th century. At least 27 eruptions (fig. 3; table III) were reported in the islands of S. Miguel, Pico, S. Jorge, Faial and Terceira, and at sea between them, although several eruptions may have been unnoticed (Zbyszewski, 1963; Weston, 1963-1964; Forjaz, 1992; Queiroz et al., 1995; Madeira, 1998). The nature and style of eruptions is variable and include trachyte plinian or subplinian events, 


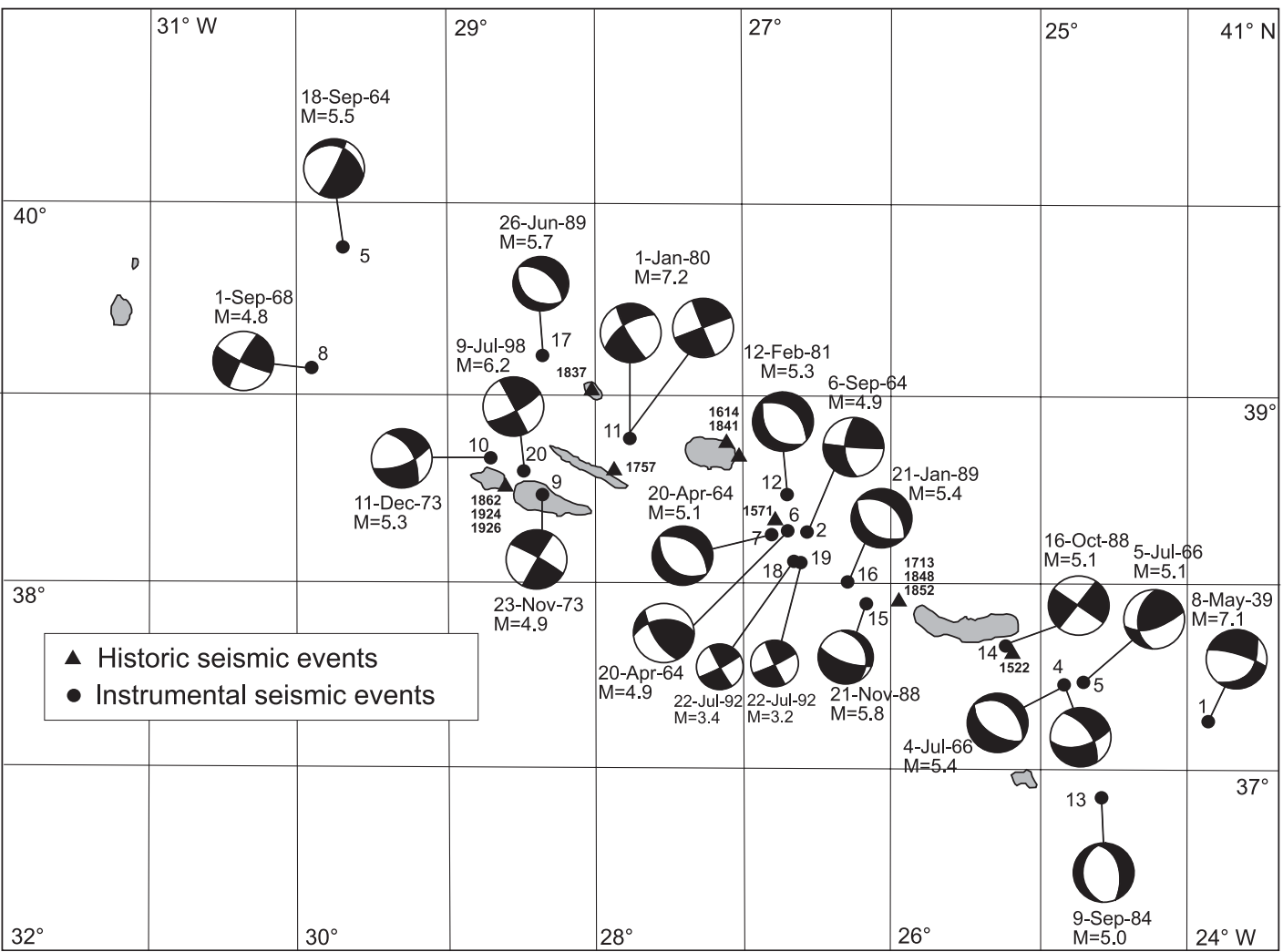

Fig. 2. Seismicity in the Azores: main historic tectonic earthquakes (triangles) and published focal mechanisms of instrumental events (circles) (data from McKenzie, 1972; Udías et al., 1976, 1986; Hirn et al., 1980; Udias, 1980; Grimison and Chen, 1986; Moreira, 1991; Nunes, 1991; Miranda et al., 1998). Numbers relate to table II.

basaltic Hawaiian/Strombolian, shallow surtseyan or deeper submarine eruptions, and basic or acid hydrovolcanic explosions.

\section{Neotectonics of Faial, Pico and S. Jorge}

Two main fault systems were recognized in the studied islands. The dominant structures, striking WNW-ESE (N60-80W) and dipping $60^{\circ}$ to $90^{\circ}$ to $\mathrm{NNE}$ or to SSW, control the general shape of the islands. The second fault system, trending NNW-SSE (N10-30W) and dipping $60^{\circ}$ to $90^{\circ}$ to WSW or to ENE, although important, is less frequent (figs. 4, 11 and 14).
The size of the islands limits the observation of the full length of the faults. Volcanism is controlled by the tectonic structure: intersection of the two fault systems determines the location of polygenetic volcanoes, while monogenetic volcanoes lie mainly on WNW-ESE structures (Madeira and Ribeiro, 1990; Madeira, 1998).

Splays, duplexes, en échelon structures, and frequent changes in trend, portray the map geometry of the faults. In section, the fault planes display variations in dip, sometimes alternating almost vertical with less steep inclinations. At the outcrop scale, the non-planar geometry of the fault surfaces results in the formation of open spaces along strike as well as along dip. 
Table II. Seismic events with published focal mechanisms.

\begin{tabular}{|c|c|c|c|c|c|}
\hline $\mathrm{N}$. & Date & Magnitude & Location & Depth & References \\
\hline 1 & May 8, 1939 & 7.1 & $37.4 \mathrm{~N}-23.9 \mathrm{~W}$ & & $2,4,6,7$ \\
\hline 2 & Sept. 6, 1964 & 4.9 & $38.3 \mathrm{~N}-26.6 \mathrm{~W}$ & & $2,4,6,7$ \\
\hline 3 & Sept. 18, 1964 & 5.5 & $39.8 \mathrm{~N}-29.7 \mathrm{~W}$ & & $2,4,6$ \\
\hline 4 & July 4, 1966 & $5.3-5.4$ & $37.51 \mathrm{~N}-24.75 \mathrm{~W}$ & $12 \pm 5 \mathrm{~km}$ & $1,2,4,5,6,7$ \\
\hline 5 & July 5, 1966 & $5.1-5.0$ & $37.6 \mathrm{~N}-24.7 \mathrm{~W}$ & & $2,4,6,7$ \\
\hline 6 & April 20, 1968 & 4.8 & $38.3 \mathrm{~N}-26.7 \mathrm{~W}$ & & 7 \\
\hline 7 & April 20, 1968 & $5.0-5.1$ & $38.30 \mathrm{~N}-26.77 \mathrm{~W}$ & $15 \pm 5 \mathrm{~km}$ & $5,6,7$ \\
\hline 8 & Sept. 1, 1968 & 4.8 & $39.16 \mathrm{~N}-29.93 \mathrm{~W}$ & & 6 \\
\hline 9 & Nov. 23, 1973 & 4.9 & $38.52 \mathrm{~N}-28.37 \mathrm{~W}$ & & 6 \\
\hline 10 & Dec. 11,1973 & 5.0 & $38.7 \mathrm{~N}-28.7 \mathrm{~W}$ & & 6,7 \\
\hline 11 & Jan. 1, 1980 & $7.2-6.4$ & $38.82 \mathrm{~N}-27.78 \mathrm{~W}$ & $10 \mathrm{~km}$ & $3,5,6,7$ \\
\hline 12 & Feb. 12, 1981 & 5.3 & $38.5 \mathrm{~N}-26.7 \mathrm{~W}$ & & 7 \\
\hline 13 & Sept. 9, 1984 & 5.0 & $36.9 \mathrm{~N}-24.6 \mathrm{~W}$ & & 7 \\
\hline 14 & Oct. 16,1988 & 5.1 & $37.70 \mathrm{~N}-25.20 \mathrm{~W}$ & & 8 \\
\hline 15 & Nov. 21, 1988 & 5.8 & $37.9 \mathrm{~N}-26.2 \mathrm{~W}$ & & 7 \\
\hline 16 & Jan. 21, 1989 & 5.4 & $38.04 \mathrm{~N}-26.28 \mathrm{~W}$ & & 8 \\
\hline 17 & June 26, 1989 & 5.7 & $39.23 \mathrm{~N}-28.34 \mathrm{~W}$ & & 8 \\
\hline 18 & July 22, 1992 & 3.2 & $38.15 \mathrm{~N}-26.65 \mathrm{~W}$ & & 9 \\
\hline 19 & July 22, 1992 & 3.4 & $38.15 \mathrm{~N}-26.65 \mathrm{~W}$ & & 9 \\
\hline 20 & July 9, 1998 & $5.8\left(M_{d}\right)-6.2\left(M_{w}\right)$ & $38.63 \mathrm{~N}-28.52 \mathrm{~W}$ & & 10,11 \\
\hline
\end{tabular}

1 - McKenzie (1972); 2 - Udías et al. (1976); 3 - Hirn et al. (1980); 4 - Udias (1980); 5 - Grimison and Chen (1986); 6 - Udías et al. (1986); 7 - Moreira (1991); 8 - Nunes (1991); 9 - Miranda et al. (1998); 10 - Vales et al. (2000); 11 - Madeira et al. (1998a).

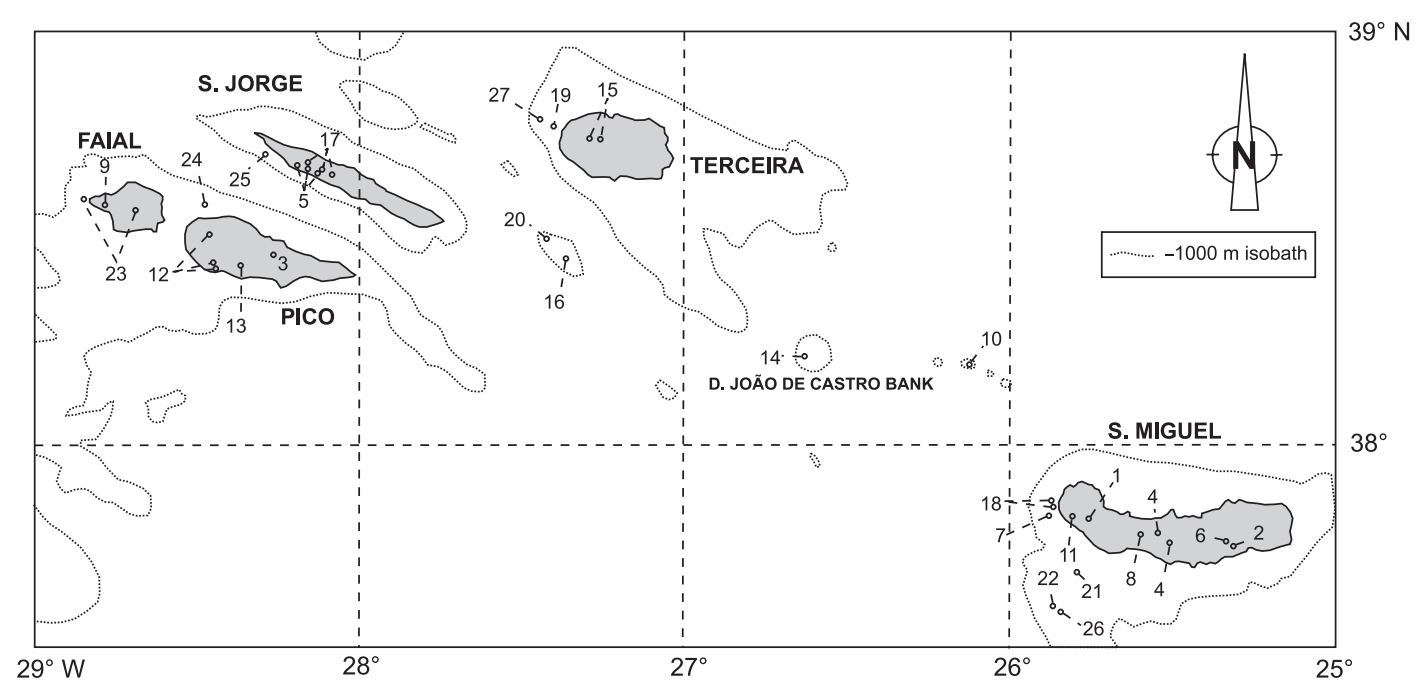

Fig. 3. Location of reported historic eruptions in the Azores (data from Zbyszewski, 1963; Weston, 1963/64; Forjaz, 1992; Queiroz et al., 1995; Madeira, 1998). Submarine eruptions occurred at depths shallower than $-400 \mathrm{~m}$. Numbers relate to table III. 
Table III. Historic eruptions in the Azores.

\begin{tabular}{|c|c|c|c|}
\hline $\mathrm{N}$. & Year & Location & Structure \\
\hline 1 & $1439 ?$ & S. Miguel & Pico da Ferraria - Sete Cidades \\
\hline 2 & 1439 or 43 & S. Miguel & Pico do Gaspar - Furnas \\
\hline 3 & $1562 / 64$ & Pico & Pico do Cavaleiro (presently Cabeços do Fogo) \\
\hline 4 & $1563 / 64$ & S. Miguel & $\begin{array}{l}\text { Lagoa do Fogo, Pico do Sapateiro (Queimado), } \\
\text { Pico de D }{ }^{\mathrm{a}} \text { Guiomar, Monte Escuro }\end{array}$ \\
\hline 5 & 1580 & S. Jorge & $\mathrm{Rib}^{\mathrm{a}}$ do Almeida, Mistério da Queimada, Rib ${ }^{\mathrm{a}}$ do Nabo \\
\hline 6 & 1630 & S. Miguel & Lagoa Seca - Furnas \\
\hline 7 & 1638 & off shore & Ponta da Candelária (S. Miguel) - $37^{\circ} 49^{\prime} 02^{\prime \prime} \mathrm{N}-25^{\circ} 52^{\prime} 03^{\prime \prime} \mathrm{W}$ \\
\hline 8 & 1652 & S. Miguel & Picos do Fogo I and II \\
\hline 9 & $1672 / 73$ & Faial & Cabeço do Rilha Boi (presently Cabeço do Fogo) and Pincarito \\
\hline 10 & 1682 & off shore & Between S. Miguel and D. João de Castro Bank $-38^{\circ} 07^{\prime} \mathrm{N}-26^{\circ} 08^{\prime} \mathrm{W}$ \\
\hline 11 & 1713 & S. Miguel & Pico das Camarinhas \\
\hline 12 & 1718 & Pico & Lomba de Fogo, Cabeço de Cima and de Baixo, off shore S. João \\
\hline 13 & 1720 & Pico & Cabeço do Soldão (or Cabeço do Fogo) \\
\hline 14 & 1720 & off shore & Formed a temporary island on D. João de Castro Bank $-38^{\circ} 14^{\prime} \mathrm{N}-26^{\circ} 39^{\prime} \mathrm{W}$ \\
\hline 15 & 1761 & Terceira & Picos das Caldeirinhas, Mistério Negro \\
\hline 16 & 1800 & off shore & Ponta do Topo (S. Jorge) - $38^{\circ} 27^{\prime} 07^{\prime \prime} \mathrm{N}-27^{\circ} 22^{\prime} 07^{\prime \prime} \mathrm{W}$ \\
\hline 17 & 1808 & S. Jorge & Craters W of Pico do Pedro, Entre Ribeiras and Areias de Santo Amaro \\
\hline 18 & 1811 & off shore & $\begin{array}{l}\text { Ponta da Ferraria (S. Miguel) - } 37^{\circ} 51^{\prime} 04^{\prime \prime} \mathrm{N}-25^{\circ} 51^{\prime} 08^{\prime \prime} \mathrm{W} \text {; } \\
\text { a temporary island (Sabrina) formed }-37^{\circ} 52^{\prime} 04^{\prime \prime} \mathrm{N}-25^{\circ} 51^{\prime} 06^{\prime \prime} \mathrm{W}\end{array}$ \\
\hline 19 & 1867 & off shore & WNW of Ponta da Serreta (Terceira) - $38^{\circ} 47^{\prime} 04^{\prime \prime} \mathrm{N}-27^{\circ} 27^{\prime} 00^{\prime \prime} \mathrm{W}$ \\
\hline 20 & 1902 & off shore & $\mathrm{W}$ of Ponta do Topo (S. Jorge) - $38^{\circ} 31^{\prime} 02^{\prime \prime} \mathrm{N}-27^{\circ} 26^{\prime} 08^{\prime \prime} \mathrm{W}$ \\
\hline 21 & 1907 & off shore & Close to south coast of S. Miguel $-37^{\circ} 41^{\prime} 05^{\prime \prime} \mathrm{N}-25^{\circ} 48^{\prime} 00^{\prime \prime} \mathrm{W}$ \\
\hline 22 & 1911 & off shore & Mónaco Bank - $37^{\circ} 36^{\prime} \mathrm{N}-26^{\circ} 52^{\prime} \mathrm{W}$ \\
\hline 23 & $1957 / 58$ & off shore & Capelinhos; phreatic explosion in Caldeira (Faial) \\
\hline 24 & 1963 & off shore & Probable eruption NW of Cachorro (Pico) \\
\hline 25 & 1964 & off shore & Probable eruption W of Velas (S. Jorge) \\
\hline 26 & 1981 & off shore & Probable eruption at Mar de Prata (SW of S. Miguel) \\
\hline 27 & $1998 / 00$ & off shore & WNW of Ponta da Serreta (Terceira) \\
\hline
\end{tabular}

Modified from Madeira (1998), based on Zbyszewski (1963); Weston (1963/64); Forjaz (1992), Queiroz et al. (1995) and coeval written accounts.

The kinematics of the faults, deduced from striated fault surfaces, as well as from the displacement of morphologic (e.g., spatter cones, streams and ridges) and stratigraphic markers, indicates normal dextral slip on the WNW-ESE fault system and normal sinistral displacement in the NNW-SSE conjugate system. Small pullapart basins and push-ups are related to releasing and restraining bends, respectively. Morphologic features such as fault scarps, sag ponds, alignments of volcanic cones and craters, displaced streams and craters, characterize the fault traces.

Major faults usually have well-developed scarps with metric to hectometric heights.
However, the fault scarps height may not correspond directly to the accumulation of successive surface rupture. Often, differential erosion of the disrupted materials (lava flows versus pyroclasts) or partial fossilization of the scarp by volcanism may amplify or attenuate the tectonic slope. On the up-thrown block, secondary fault scarps, showing en échelon geometry, are frequent.

Observation of striated fault surfaces indicates that, besides oblique slip, strain partitioning may occur at the fault zone scale: parallel slip surfaces from a fault zone displaying either dip slip or strike slip slickensides, show that strike and normal components may be separated in time or space. The occurrence in the archi- 
pelago of earthquakes with normal and strike slip focal mechanisms in parallel faults, separated by a few kilometers or tens of kilometers, suggests that strain partitioning may also occur at the regional scale (Madeira, 1998).

\subsection{Faial}

\subsubsection{Geological and structural setting}

The island of Faial is $21 \mathrm{~km}$ long, has a maximum width of $14 \mathrm{~km}$, and reaches an altitude of $1043 \mathrm{~m}$ at Cabeço Gordo (fig. 4).

Two central volcanoes and two fissural volcanic zones form the sub aerial part of the island (Serralheiro et al., 1989; Madeira, 1998; Pacheco, 2001). The 800-580 Ka old (Féraud et al., 1980) Ribeirinha shield volcano constitutes the eastern region of Faial. It is predominantly composed of sub aerial hawaiitic lava flows mapped under the designation of Ribeirinha Volcanic Complex ( $\mathrm{Rb}$ in fig. 4). The Caldeira stratovolcano was built on the western flank of the Ribeirinha volcano and constitutes the main relief of Faial. It is approximately $15 \mathrm{~km}$ in diameter at sea level; the summit is truncated by a $2 \mathrm{~km}$ wide, $400 \mathrm{~m}$ deep, caldera. The products of this volcano range from basalts to trachytes and are divided into two volcanostratigraphic units. The lower unit, Cedros Volcanic Complex ( $\mathrm{Cd}$ in fig. 4), is mainly composed of sub aerial basalt to benmoreite lava flows. The available ages for this unit range from $\sim 470$ to $11 \mathrm{Ka}$ (Féraud et al., 1980; Baubron, 1981 in Chovelon, 1982). The upper unit, Caldeira Formation ( $\mathrm{p}$ and $\mathrm{i}$ in fig. 4), corresponds to a Holocene sequence of trachytic products, emplaced by explosive eruptions. Radiocarbon ages from Caldeira Formation products range from $\sim 10$ to $1 \mathrm{Ka}$ (Madeira et al., 1995).

A basaltic fissural unit, the Almoxarife Formation (Al in fig. 4), overlies the southeastern slope of Caldeira volcano and is covered by Caldeira Formation pyroclasts. It comprises Hawaiian/Strombolian scoria cones and lava flows and one surtseyan cone. The only available age for this formation is a low quality $\mathrm{K} / \mathrm{Ar}$ date of $0.03 \pm 0.02 \mathrm{Ma}$ (Féraud et al., 1980).
The western region of Faial is formed by a dextral en échelon alignment of basaltic Hawaiian/Strombolian and surtseyan cones and lava flows, the Capelo Volcanic Complex (Cp in fig. 4 ), built on the west slope of Caldeira volcano. It is younger than 10000 years (as it overlies the oldest pyroclasts of Caldeira Formation), and includes two historical eruptions (1672 and 1957 in fig. 4).

As already mentioned, the active faults control the general shape of the island (fig. 4). The eastern part of Faial Island is characterized by a WNW-ESE trending graben structure (Pedro Miguel Graben) composed of seven normal dextral faults: Ribeirinha (R) (fig. 5), Chã da Cruz (CC), Lomba Grande (LG), Ribeira do Rato (RR), Rocha Vermelha (RV), Espalamaca (E) and Flamengos $(\mathrm{F})$ faults. The graben is partially fossilized by Holocene pyroclastic fall and flow deposits from the Caldeira Formation in the central area of the island. Other WNW-ESE important faults are located south of the caldera (Lomba do Meio - LM, and Lomba de Baixo $\mathrm{LB}$, faults) and in the western part of the island (Ribeira do Adão - RA; Ribeira das Cabras - RC; Ribeira Funda - RF, and Capelo - C, faults).

The conjugate fault system, trending NNWSSE to NW-SE, composed of normal left lateral faults, is secondary in importance: geomorphic expression is less developed and lengths are smaller. Between the southern rim of the caldera and the Lomba do Meio Fault these structures are more abundant (inset in fig. 4) displacing and controlling the smaller order drainage. The longer faults are those of ÁguaCutelo (AC), Salão (S), and Cedros (CD).

\subsubsection{Historical seismicity - the 1958 earthquake swarm}

There are no records of earthquakes felt in Faial until the 1614 event that struck Terceira Island. However, significant local earthquakes only occurred during the 20th century, almost 500 years after settlement. The 1924 earthquake, the 1926 seismic swarm, and the 1998 event caused important damage in Eastern Faial. In 1958, a seismic swarm, contemporary of the Capelinhos eruption, caused buildings 


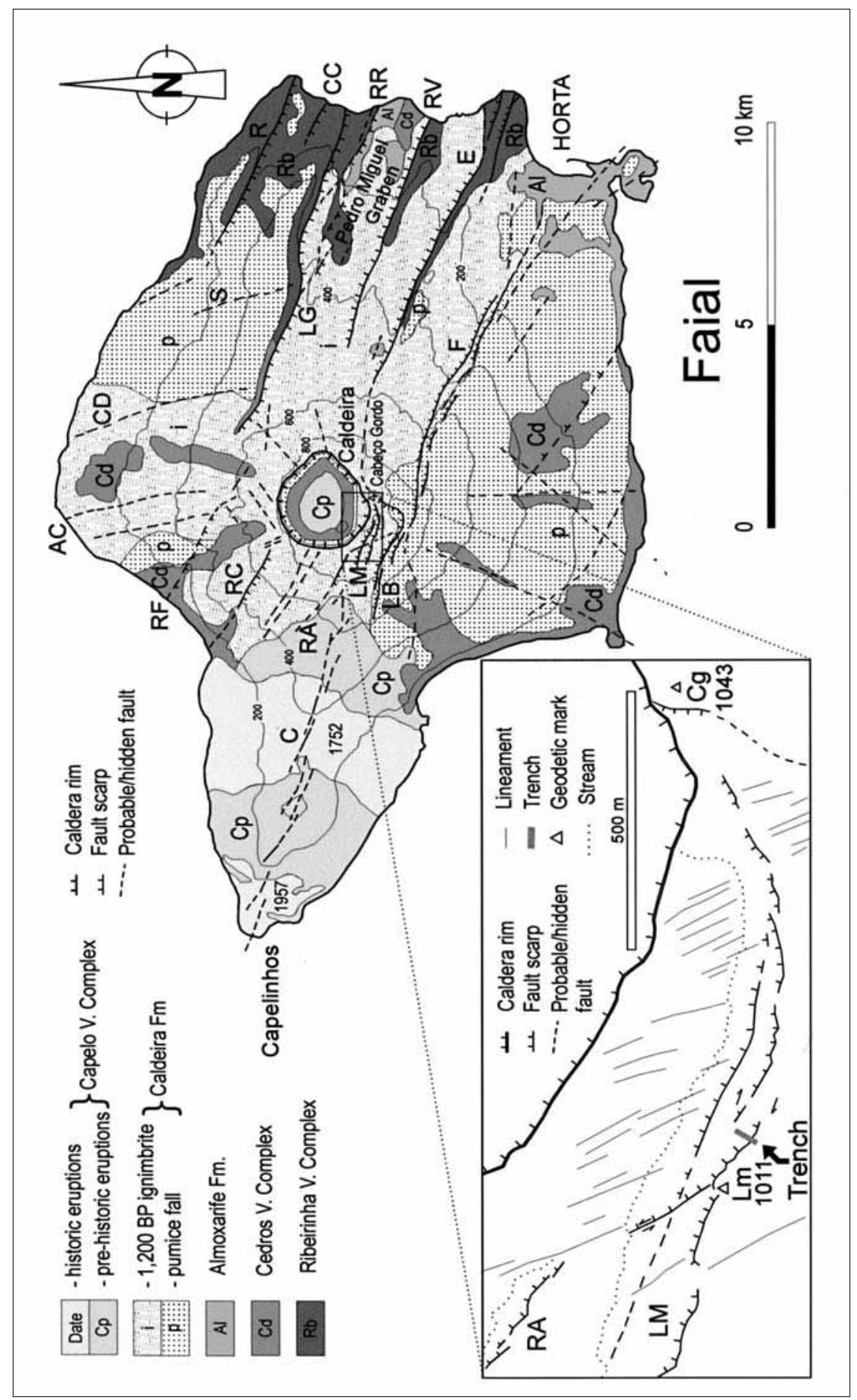

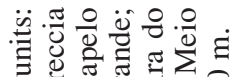

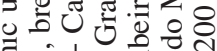



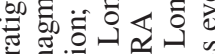
के

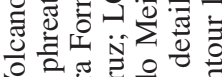

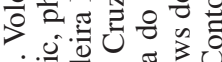

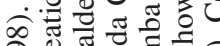
大

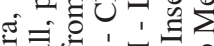

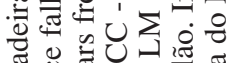

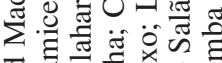

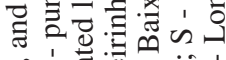
它. : 1 है

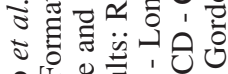
원.

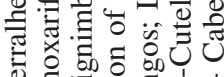

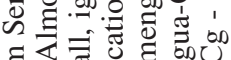

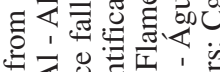

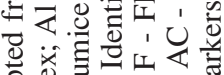
券

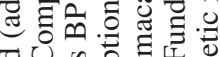

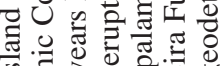

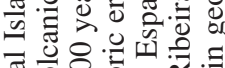

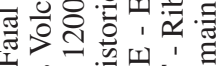

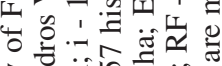

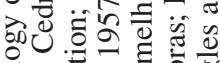

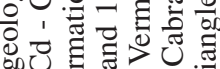

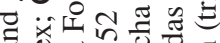
\%

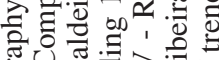

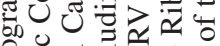

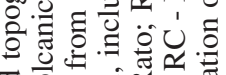

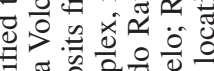

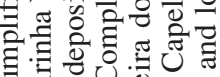

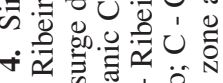

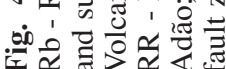




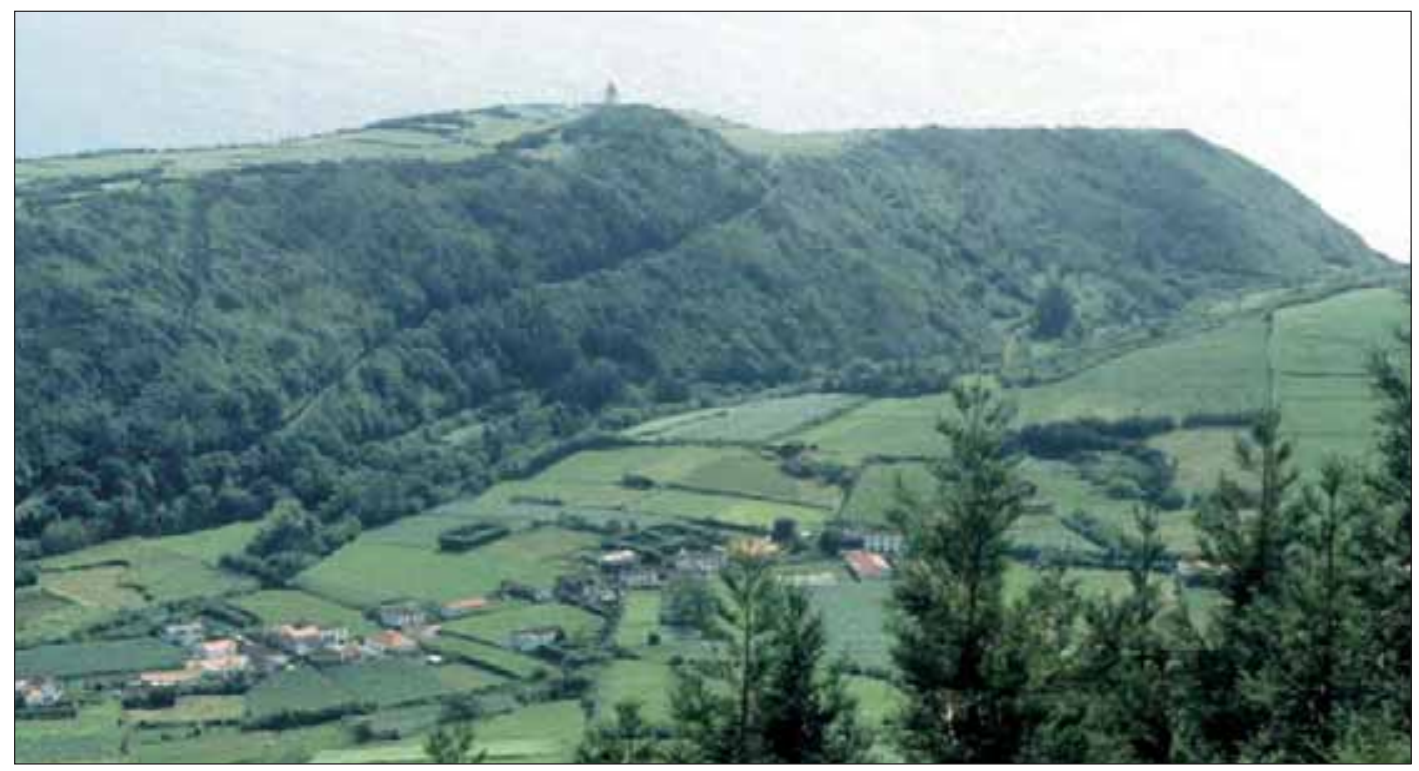

Fig. 5. Fault scarp of Ribeirinha Fault, in NE Faial, viewed from the west. Ribeirinha village in the down threw block gives the scale. The observed maximum height of scarp is $120 \mathrm{~m}$ in the centre of photograph.

collapse and ground deformation along faults in central and western areas of the island.

The 1958 seismic swarm started in May 12, and continued until June. During the first three days of most intense seismic activity, 450 earthquakes, some of which reaching intensities VIII and IX (MCS-17 scale) in the epicentral region (Western Faial), were felt. Seismicity caused total collapse of 508 houses and heavy damage in 1000. Housing was (and still is in many rural areas) characterised by low quality, highly vulnerable, one or two storeys high, stone buildings (A and B vulnerability classes according to the 1998 European Macroseismic Scale; Grünthal, 1998). The stronger earthquakes caused surface deformation along several faults (Capelo, Lomba do Meio, Lomba de Baixo, Ribeira do Adão, Ribeira das Cabras, Lomba Grande, and Espalamaca); mainly ground cracking but, locally, 0.5 to $1 \mathrm{~m}$ vertical displacements were reported. Photographs of ground cracks also suggest right lateral slip (fig. 6a,b; Zbyszewski and Ferreira, 1959). Widening or narrowing of ground fissures during the first two weeks of the seismic swarm is also referred (Tazieff, 1959; Zbyszewski and Ferreira, 1959). However, these effects were never studied in detail or mapped because attention was focussed on the ongoing eruption. At the epoch only 3 seismic stations existed in the archipelago (installed in 1902 in S. Miguel and Faial, and in 1932 in Terceira; Silveira, 2002), but the equipment in Faial was inoperative at the time. Presently a few tension cracks still persist along fault scarps in the up-thrown block of Lomba do Meio Fault.

\subsubsection{Geometry, kinematics and geomorphic expression of Lomba do Meio Fault}

The southern slope of the Caldeira Volcano is crossed by the north dipping Lomba do Meio (inset in fig. 4; fig. 7) and Lomba de Baixo faults. To the east, the Lomba do Meio Fault links with the Espalamaca Fault through a restraining bend that follows the west and north slopes of the Cabeço Gordo height, which is 

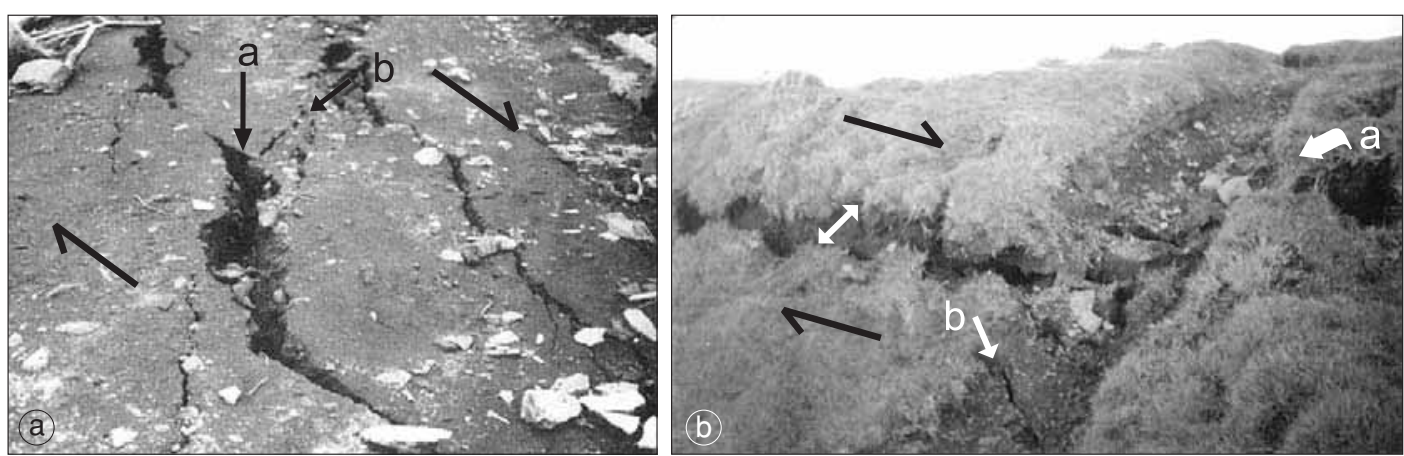

Fig. 6a,b. Examples of surface deformation produced during the May 1958 seismic swarm in the island of Faial: a) pull apart tension cracks $(a)$ in dextrally sheared dirt road in Praia do Norte. NNW-SSE conjugate system $(b)$ is also present; b) surface rupture along fault scarp in Cabeço Gordo area. Note normal dextral displacement of surface irregularities $(a)$ and fractures with the orientation of conjugate system $(b)$. Similar features were observed in Faial after the July 9th, 1998, earthquake. Photographs reproduced from Zbyzewski and Veiga Ferreira (1958) with kind permission of Instituto Geológico e Mineiro.

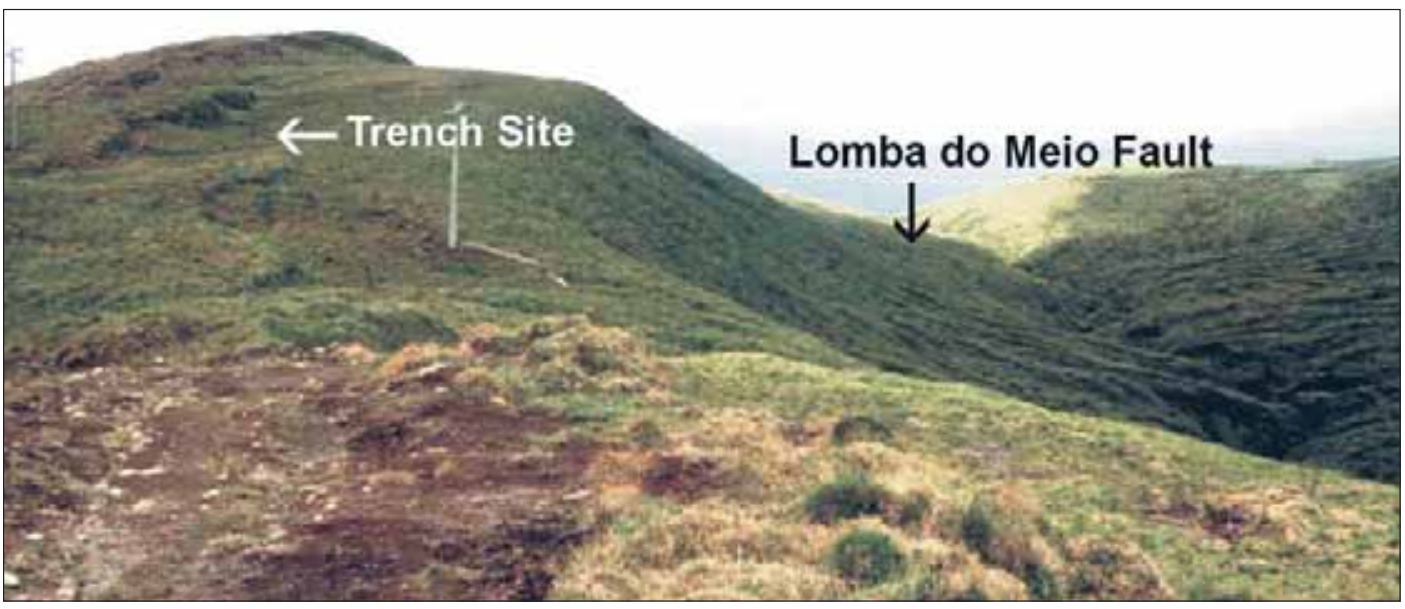

Fig. 7. Fault scarps of Lomba do Meio Fault, in central Faial, viewed from the east. The main fault scarp is 50-60 m high, but is amplified by fluvial incision. Notice dextral en échelon secondary scarps in up-thrown block. Trench was open in front of the most distant electric pole (left side of photo).

interpreted as a push-up structure. To the west, it links to Capelo Fault, a fracture system defined by the alignment of cones and craters of Capelo Volcanic Complex (< $10 \mathrm{ka})$, displaying right lateral en échelon geometry, which extends to Capelinhos volcano in the western tip of Faial. In this particular area, Capelo Fault is expressed by tens of sub-vertical fractures, concentrated in a $250 \mathrm{~m}$ wide zone, cutting trough the pyroclastic sequence of a surtseyan cone exposed in a paleo-sea cliff east of Capelinhos volcano. These fractures display an accumulated NE down throw of $50 \mathrm{~cm}$. Thus, the Capelo, Lomba do Meio and Espalamaca faults constitute three 
sections of the same tectonic structure, characterized by normal dextral slip.

The Lomba do Meio Fault geomorphic expression is a $50 \mathrm{~m}$ high, north facing, fault scarp coupled with a set of right lateral en échelon secondary fault scarps on the up-thrown block (fig. 7). A trench was open across one of these secondary en échelon scarps, where surface rupture was reported in the 1958 seismic swarm. Other reasons for this location were the size of the main LM Fault Scarp, fresh aspect and pyroclastic constitution of the secondary fault scarps.

\subsubsection{Paleoseismic analysis of Lomba do Meio Fault}

The trench exposed a sequence of pyroclastic deposits and colluvial wedges displaced by a fault zone composed of three main fault planes (A1, B and C) defining a graben and horst structure (figs. 8 and 9). Fault plane B is responsible for the fault scarp, which is slightly degraded. Stratigraphy is composed of trachyte $(1,2,3,4,5,6,7)$ pyroclastic fall and flow deposits, basaltic ash fall layers $(9,11)$, and colluvial wedges $(8,10,12,13)$; the sequence ends with the topsoil.

Only one radiocarbon age was derived from the trench; however, it was possible to correlate some of the volcanic deposits exposed in the trench with volcanic layers radiocarbon dated outside the trench (Madeira et al., 1995; table IV). On the basis of these stratigraphic correlations, $2 \sigma$ intervals of dendrochronologically calibrated radiocarbon ages of units 4,5 and 7 are: unit 4-1878 to 1420 cal B.C.; unit 5-259 to 536 cal A.D.; unit 7-890-1040 cal A.D. For unit 6 a radiocarbon age of $1500 \pm 50 \mathrm{BP}$ was determined, but no calibrated dates are available. Unit 12 was dated using a fragment of wood preserved in the base of colluvial wedge that yielded a $2 \sigma$ calibrated age interval of 1290 1640 cal A.D.

The evolution of the fault zone was deduced from geometric analysis, nature, and composition of the deposits exposed on the trench, and indicates the following events (graphically represented in fig. 10a-o): a) Deposition of pyroclastic sequence 1 to 5 (deposit 5 is 259 to 536 cal A.D.).

b) Surface rupture at fault planes A1, A2 and C (seismic event 1-SE1) after deposition of pyroclast 5 and before the erosive episode that created the unconformity on which rests pyroclasts $6(1500 \pm 50 \mathrm{BP})$. SE1 is marked by different thickness of layer 5 preserved below layer 6: layer 5 was totally eroded from the higher block (north of fault C) and partially removed south of fault $\mathrm{C}$, presenting different thickness in the central $(50 \mathrm{~cm})$ and southern (at least 65 $\mathrm{cm})$ tectonic blocks. This indicates that normal separation on the faults was at least $50 \mathrm{~cm}$ in fault $\mathrm{C}$ and $15 \mathrm{~cm}$ in fault $\mathrm{A}$. The event horizon (the top of 5) marking this rupture was not preserved due to erosion after SE1.

c) Erosion of fault scarps with levelling of topography. Deposition of pyroclast 6 . Formation of a soil on 6. Deposition of layer 7 (between 890 and $1040 \mathrm{cal} \mathrm{A.D.).}$

d) Surface rupture on fault plane A1 and A2 with normal separation of $80+15 \mathrm{~cm}$ (SE2). The $80 \mathrm{~cm}$ displacement in fault A1 was determined from the separation in the base of layer 7 , taking into account the thickness of layers 5 and 6 , preserved between faults $\mathrm{B}$ and $\mathrm{C}$, and missing in the block between faults $\mathrm{A} 1$ and $\mathrm{B}$; the $15 \mathrm{~cm}$ separation were measured in lithic rich layers in pumice 4 displaced by fault $\mathrm{A} 2$.

e) Erosion degrades fault scarp and truncates layer 7 .

f) Surface rupture on fault plane B $(\mathrm{SE} 3)\left({ }^{*}\right)$; normal separation must have exceeded $2 \mathrm{~m}$ in order to expose pumice deposit 4 (which will contribute to the formation of colluvial wedge 8 ) in the fault scarp; this value was obtained from the thickness of layers 5, 6, 7 added to the preserved thickness of colluvial wedge 8 .

*) There is no preserved event horizon for SE2 (the top of layer 7), which we believe was eroded between SE2 and SE3. In fact, there is no direct evidence to separate the two seismic events. If we consider surface rupture in both faults (A1 and C), a narrow horst structure would be created and a synthetic fault, generating a fault scarp further south, would be needed to root fault A. There is no evidence of such a scarp, which suggests that SE2 is an earlier event. Furthermore, horst structures are not observed in any of the up-thrown faulted blocks in the archipelago. 


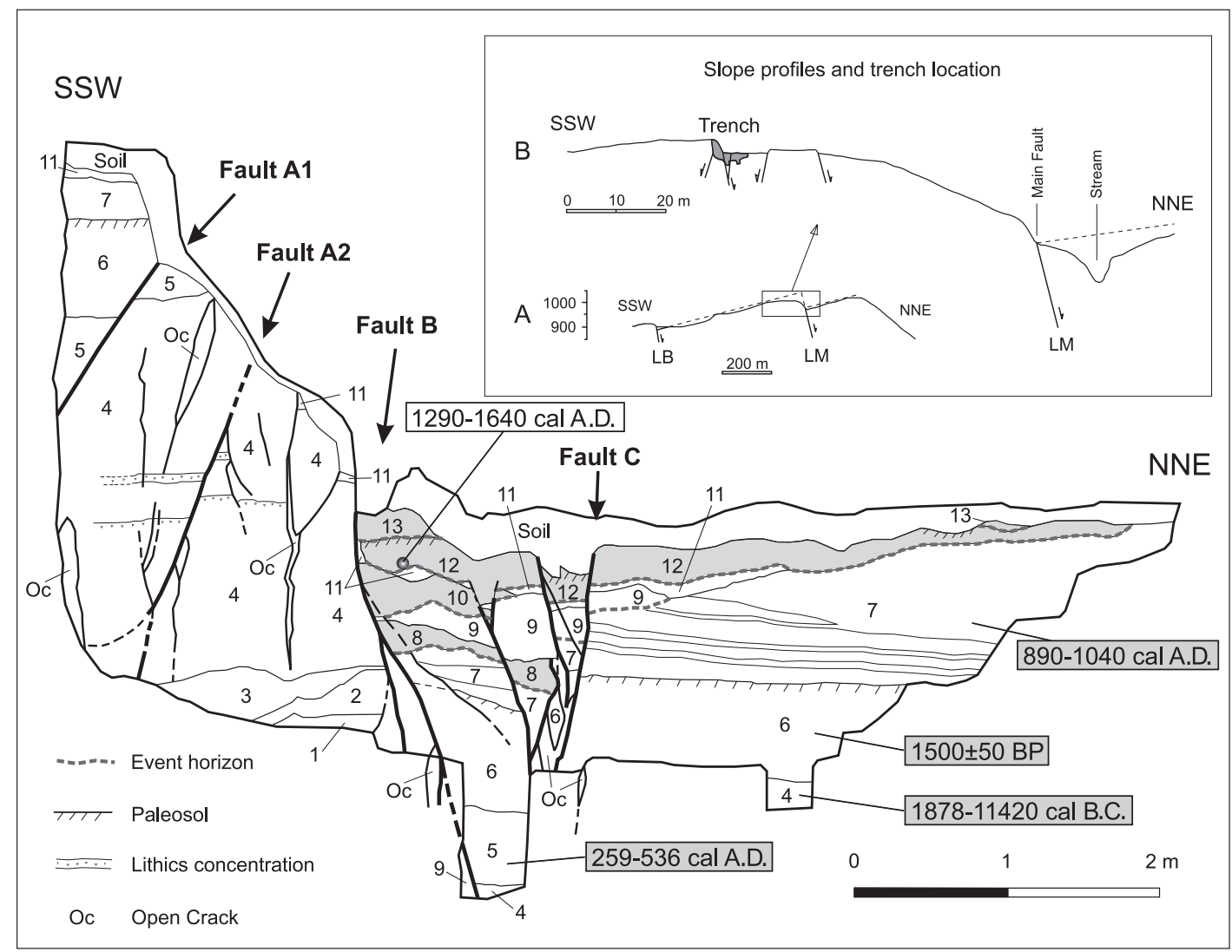

Fig. 8. Simplified and reduced (originally at the $1 / 10$ scale) map of the Lomba do Meio trench west wall showing three main faults related to LM fault zone. Fault B is related to the present fault scarp, which is slightly degraded. Stratigraphic sequence exposed in the trench is composed of: 1 - trachyte hydromagmatic explosion breccia; 2 - trachyte explosion breccia (or colluvium?); 3 - trachyte weathered ash layer (or colluvium?); 4 - trachyte pumice fall deposit, with a massive structure except for a few lithic rich layers; 5 - trachyte massive phreatomagmatic pyroclast composed of fine ash and lithics; 6 - trachyte weathered pyroclast grading from lapilli to fine ash overlying an erosive surface cut on 5 and $4 ; 7$ - trachyte phreatomagmatic surge deposit with alternating fine ash and lapilli layers; the base is an erosive surface; 8 - wedge shaped colluvium made of pumice and lithics from level 4; the base is an erosive surface; 9 basaltic fine ash fall layer deposited on an erosive surface; the ashes fell into, and partially filled, open cracks below; 10 - wedge shaped colluvium made of pumice and lithics from level 4 and basaltic ash from level 9; the base is an erosive surface; 11 - discontinuous basaltic fine lapilli layer; it rests on 4, 7, 9 and 10 trough an erosive surface; 12 - wedge shaped colluvium containing pumice and lithics from level 4 and basaltic lapilli from level 11; 13 - wedge shaped colluvium containing pumice and lithics from level 4 and turfaceous material similar to that of the soil developed on 12; the sequence ends with the present turfaceous soil which was displaced by fault plane B during the 1958 seismic swarm. Inset shows slope profiles across the fault and location of trench: A - smaller scale profile across Lomba de Baixo (LB) and Lomba do Meio (LM) faults (vertical and horizontal scales equal; vertical scale indicates altitude in metres); B - profile of main Lomba do Meio Fault and associated secondary faults in up-thrown block (dashed lines represent original topography before erosion). Radiocarbon calibrated dates of deposits ( $2 \sigma$ intervals) indicated: dates obtained outside the trench, attributed by correlation of deposits, in grey rectangles. 


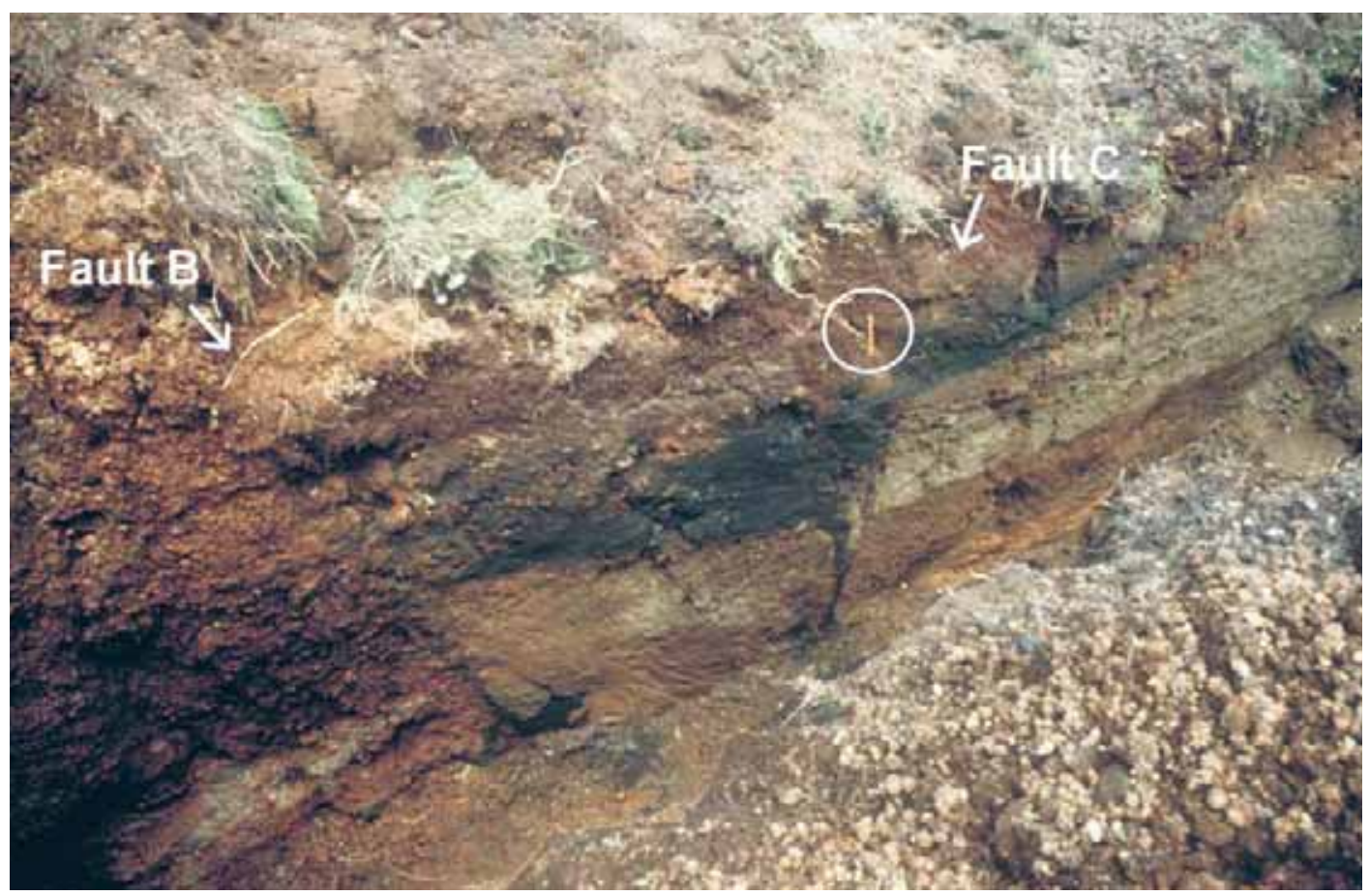

Fig. 9. Oblique view Lomba do Meio trench west wall from outside the trench. A small graben, in the centre of the trench, is bound by faults B and C. Darker deposit in centre of graben is basaltic ash 9. To the left (south) of fault $B$ is pumice 4 . To the right of fault $C$ deposits 6,7 and basaltic ashes 9 and 11 are easily distinguishable. A pen (enclosed by circle) gives scale.

g) Fault scarp retreat and formation of colluvial wedge 8 , composed of pumice of layer 4 and basaltic lithics from layers 5, 6 and 7 . Deposition of a basaltic ash layer (9) correlative of a basaltic eruption. Erosion and partial removal of basaltic ashes.

h) Surface rupture in fault planes B and C (SE4); in fault B the value of normal separation is unknown, but must have exposed pumice of layer 4 in the fault scarp; in fault plane $\mathrm{C}$ vertical separation was equal or smaller than $9 \mathrm{~cm}$.

i) Fault scarp retreat and formation of colluvial wedge 10, composed of ashes from layer 9, pumice from 4, and lithics from 5,6 and 7. Deposition of basaltic ashes (11) correlative of a basaltic eruption. Partial erosion of basaltic ashes that became discontinuous. j) Surface rupture of fault plane B with normal separation of unknown value (SE5).

k) Fault scarp retreat and formation of colluvial wedge 12, composed of ashes from 11, pumice from 4, and basaltic lithics. A soil developed on the colluvium. Calibrated radiocarbon age of a wood fragment from the base of the colluvium is $1290-1640$ cal A.D.

1) Surface rupture in fault planes B (unknown separation) and $\mathrm{C}$ (vertical separation of $11 \mathrm{~cm})($ SE6).

m) Fault scarp retreat and formation of colluvium 13, composed of pumice, basaltic ashes, basaltic lithics and turfaceous soil fragments from layer 12 .

n) Erosion truncates colluvia 12 and 13; colluvium 13 became discontinuous. Development of present top soil (14). 


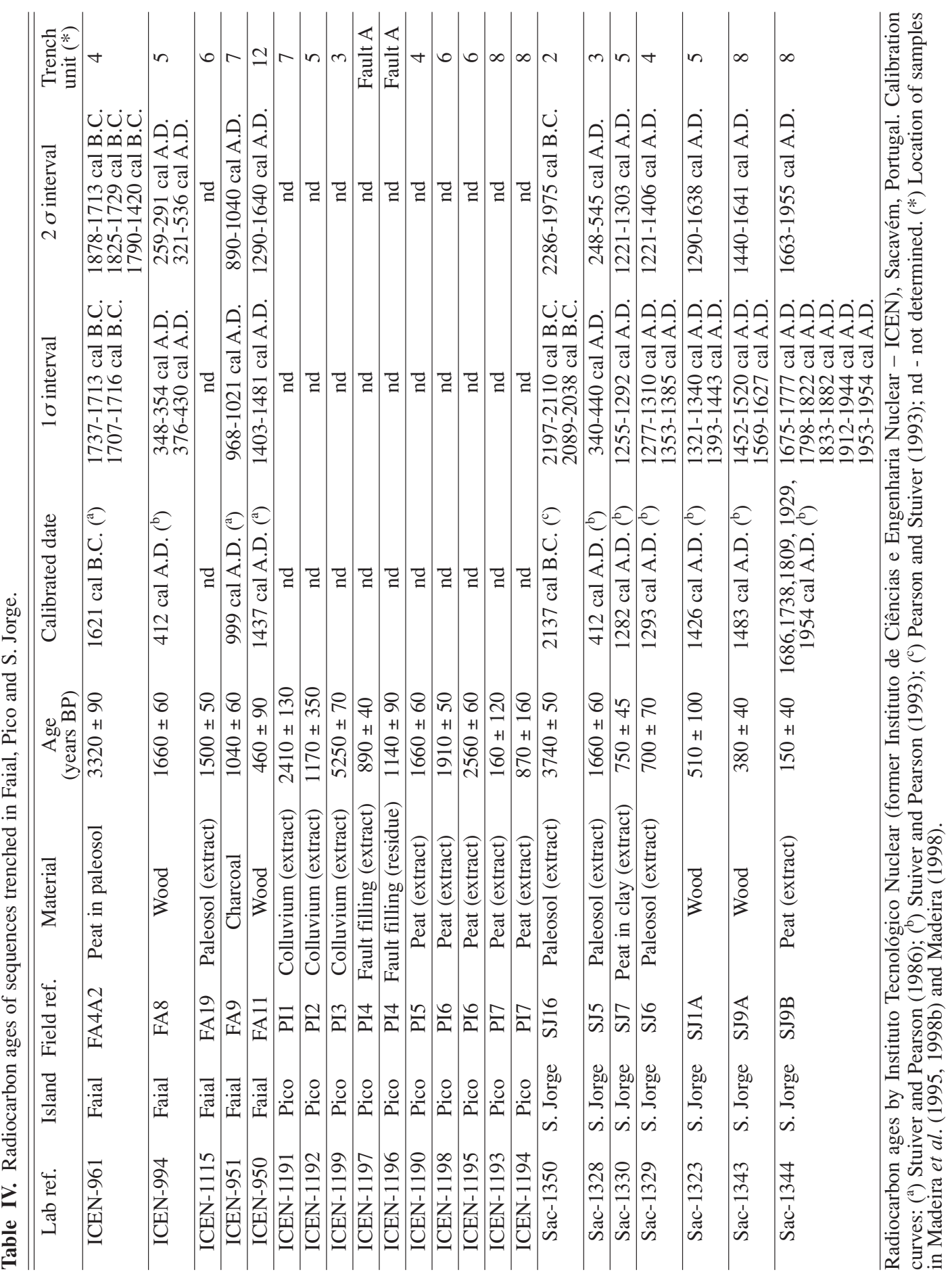



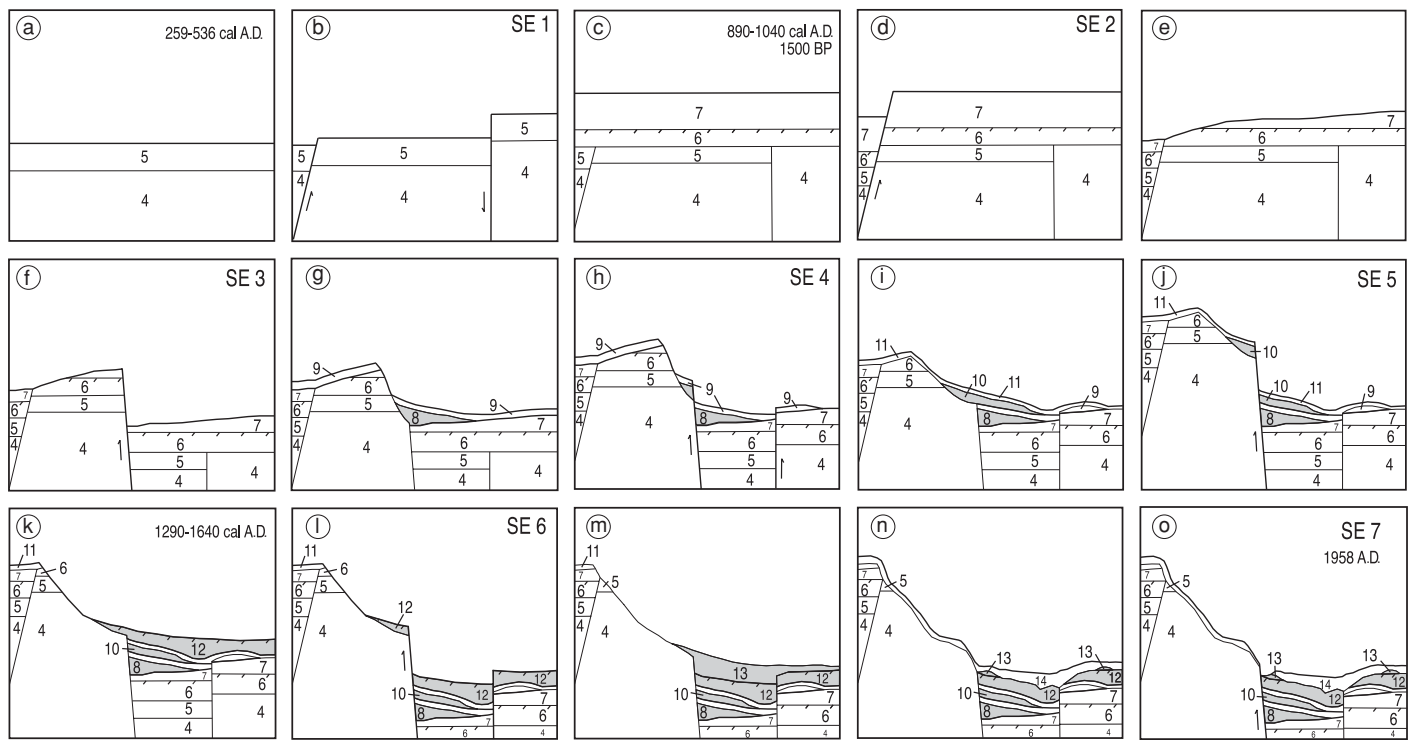

Fig. 10a-o. Sequence of events (tectonic, depositional and erosional) leading to present day geometry exposed in Lomba do Meio trench. Radiocarbon-dated deposits and surface rupturing seismic events (SE 1-7) indicated. Full description in text.

o) Surface rupture on fault plane B (vertical separation of $15 \mathrm{~cm}$ ?). This event (SE7) is assigned to the May 1958 seismic swarm.

Thus the Lomba do Meio trench revealed 7 surface rupturing seismic events in $1606 \pm 138$ years that can be summarized as follows:

1) The older event occurred between 259 to 536 cal A.D. and about 400 to 500 years before deposition of layer 7 (890 to 1040 cal A.D.) involving fault planes $\mathrm{A} 1, \mathrm{~A} 2$, and $\mathrm{C}$ and an accumulated normal separation exceeding $65 \mathrm{~cm}$.

2) The following four events occurred between 890 to $1040 \mathrm{cal}$ A.D. and 1290 to 1640 cal A.D.; the second event reactivated fault planes A1 and A2 and produced vertical separations of 80 and $15 \mathrm{~cm}$ respectively; the third event produced rupture in fault plane $\mathrm{B}$ and a separation exceeding $2 \mathrm{~m}$ in order to expose the pumice deposit in the fault scarp; the fourth event reactivated fault planes $\mathrm{B}$ and $\mathrm{C}$ with unknown normal separation (probably $>70 \mathrm{~cm}$, deduced from the preserved thickness of collu- vium 10) in fault B and $\leq 9 \mathrm{~cm}$ in fault plane $\mathrm{C}$, producing $\sim 60 \mathrm{~cm}$ of down-throw to the north; the fifth event involved fault plane B producing normal separation of unknown value (probably $>60 \mathrm{~cm}$ ) and may be related to deposition of colluvial wedge 12 (between 1290 and 1640 cal A.D.); this event preceded settlement.

3) The sixth event reactivated fault planes $\mathrm{B}$ (unknown normal separation, possibly $\sim 50$ $\mathrm{cm}$ ) and $\mathrm{C}$ (vertical separation of $11 \mathrm{~cm}$ ). There is no historic written record of this event, which probably occurred just before settlement (around 1450 A.D.).

4) The last event involved fault plane B during the May 1958 seismic swarm, producing a vertical separation of $\sim 15 \mathrm{~cm}$ at the trench site.

Time distribution of the 7 events shows one cluster of 5 events in a $510 \pm 100$ calendar years period, separated by $\sim 500$ years intervals between the first and the last events.

The average recurrence interval is $229 \pm 20$ years, but the recurrence interval during the 
cluster is $102 \pm 20$ years with clusters separated by approximately 500 years intervals.

The exposed fault planes are certainly linked to the main Lomba do Meio Fault Zone at depth, in which antithetic faults develop in relation to synthetic splays of the main plane. Fault plane $\mathrm{C}$ should branch into fault plane B, and fault planes A1 and A2 may be linked to an undetected synthetic fault further south.

Accumulated slip in the sampled $\sim 1600$ years period is $>1.10 \mathrm{~m}$ in fault planes $\mathrm{A} 1+\mathrm{A} 2$, in fault plane B it was $4.20 \mathrm{~m}$, and $0.70 \mathrm{~m}$ in fault plane C. As planes $\mathrm{A}$ and $\mathrm{C}$ are antithetic to the Lomba do Meio main fault, the trenched portion of the fault zone produced a net downthrow of $2.40 \mathrm{~m}$ to the north in $\sim 1600$ years. However, after 890 to 1040 cal A.D., fault plane $B$ accumulated $4.20 \mathrm{~m}$, while in fault plane C only $0.20 \mathrm{~m}$ of antithetic normal slip occurred, thus yielding $4 \mathrm{~m}$ of down throw to the north in a 1113 to 963 years period.

Slip rate deduced from Lomba do Meio trench data is 3.6 to $4.2 \mathrm{~mm} /$ year. Considering that the Lomba do Meio main fault produced 50-60 $\mathrm{m}$ down throw in pyroclasts from Caldeira Formation in the last $10-15$ ka a longerterm slip rate of 3.3 to $6.0 \mathrm{~mm} /$ year is obtained. Both slip rate values are of the same order of magnitude.

The detected displacements are just the observable normal component of slip (no markers for strike slip component were found), in just a few strands of the entire fault zone. Total net slip is certainly larger.

\subsection{Pico}

The island of Pico is $46 \mathrm{~km}$ long, has a maximum width of $15.8 \mathrm{~km}$ and reaches an altitude of $2351 \mathrm{~m}$ at Ponta do Pico (Pico volcano).

The sub aerial part of the island is composed of two central volcanoes and one fissural volcanic zone (Madeira, 1998; Nunes, 1999). The older shield volcano (Topo volcano) is partially dismantled by landslides, displaced by faulting, and covered by younger volcanics. It is composed of ankaramitic and basaltic lava flows assembled under the designation of Lajes Volcanic Complex (Lj in fig. 11); a single pub- lished K/Ar date yielded an age of $250 \pm 40 \mathrm{Ka}$ (Baubron, 1981, in Chovelon, 1982). An intermediate volcanostratigraphic unit, the Calheta do Nesquim Volcanic Complex (Cn in fig. 11), comprises fissural basaltic strombolian scoria cone alignments and associated lava flows; this unit outcrops in several areas on the eastern part of Pico. Three K/Ar ages are available for the Calheta do Nesquim Volcanic Complex ranging from $270 \pm 150$ to < $25 \mathrm{Ka}$ (Féraud et al., 1980; Baubron, 1981 in Chovelon, 1982). The Madalena Volcanic Complex is the younger unit in Pico, which includes three historic eruptions in 1562, 1718 and 1720; very fresh morphology suggests a Holocene age which is confirmed by radiocarbon dates younger than 6000 years (Madeira, 1998; Nunes, 1999). Structurally it can be divided into two sub-units: the Pico Volcano and the East Fissural Zone members (respectively $\mathrm{Mp}$ and Mf in fig. 11). Pico is a stratovolcano displaying a pit crater on its summit. The east fissural zone is composed of several alignments of Hawaiian/Strombolian scoria cones and related lava flows; these flowed over cliffs cut in older units and originated lava deltas.

Tectonic structure is characterized by two fault systems (fig. 11). The main WNW-ESE trending structures are the normal dextral Lagoa do Capitão (LC) and Topo (T) fault zones that progressively merge to the east; these define a graben structure, narrower and shallower than Pedro Miguel Graben (in Faial Island). The western portion of the graben is completely covered by the recent Pico stratovolcano $(<10 \mathrm{Ka})$ and to the east it is partially filled by lava flows and cones of the East Fissural Zone member of Madalena Volcanic Complex. Most structures on the eastern plateau of Pico, whose morphology is marked by volcanic alignments and short fault scarps, belong to this system.

The NNW-SSE trending conjugate faults are less abundant and are marked, mainly, by volcanic alignments. Although scarce, there is evidence of normal left lateral, oblique slip. The Lomba de Fogo-S. João (LF) fracture, along which the 1718 volcanic eruptions occurred, and the Santo Antonio (SA) volcanic alignment are the most obvious structures. At the outcrop 


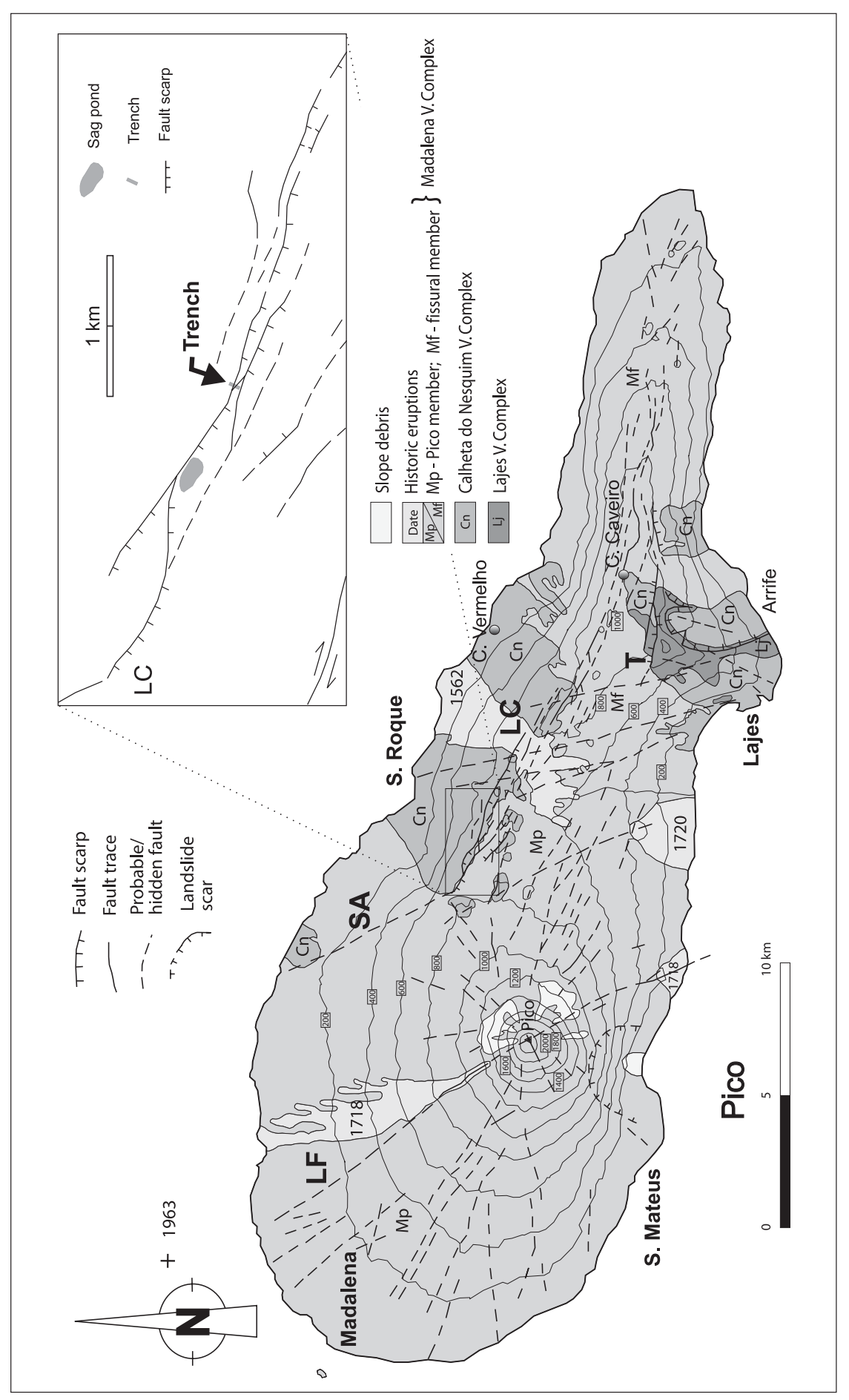

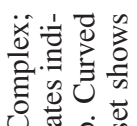

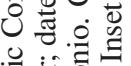

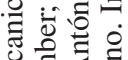

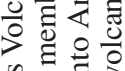

\% 의

ت대용

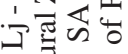

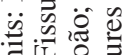

F

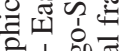

햏ํ.

to

कि है

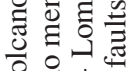

을

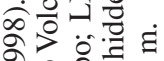

웡응

에

券完语

ह ख्य

온 웅크

屯웡

善. 용

ฮั

항

可

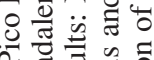

范密焉

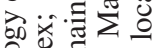

응

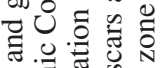

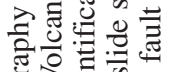

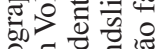

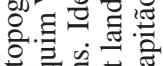

응

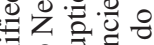

충응 흐

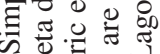

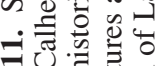

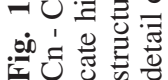



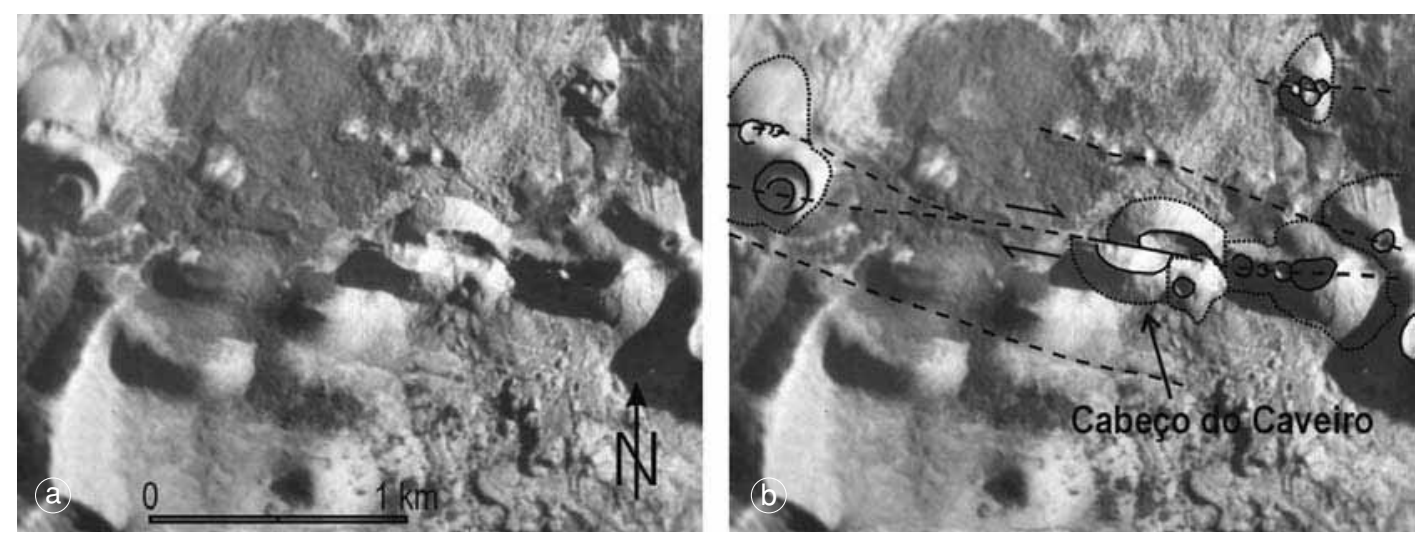

Fig. 12a,b. Vertical aerial photograph of Cabeço do Caveiro region in the island of Pico showing an example of strike-slip evidence: a) uninterpreted photo; b) interpreted photo showing base (dotted lines) and craters (arcs) of scoria cones and fault traces. Cabeço do Caveiro cone is right laterally displaced.

scale, several faults from this system were observed at Cabeço Vermelho (CV) quarry and in Lagoa do Capitão trench.

Most scoria cones occur along WNW-ESE structures, but the larger cones and Pico volcano are located at the intersection of these with the NNW-SSE conjugate faults.

At least two large gravitational (flank collapse) structures were observed on the flanks of the Pico stratovolcano and Topo shield volcano: the landslide scars of S. Mateus and Arrife.

\subsubsection{Geometry, kinematics and geomorphic expression of Lagoa do Capitão Fault}

The Lagoa do Capitão Fault Zone runs WNW-ESE for at least $30 \mathrm{~km}$ in the central and eastern areas of the Island of Pico. It has complex map geometry, with duplexes and splays, and presents a set of south facing, $9 \mathrm{~km}$-long, fault scarps (inset in fig. 11) that reach a maximum height of $20 \mathrm{~m}$. Towards the east, the scarps disappear under recent scoria cones, one of which formed during the 1562-1564 eruption, but the fault trace is marked by alignments of craters. Several sag ponds are associated with this fault zone, the most important of which is
Lagoa do Capitão (Captain's lake). To the west, the Holocene volcanic pile of Pico stratovolcano buries the fault.

The Lagoa do Capitão Fault zone displaces right laterally a few older scoria cones (for example Cabeço do Caveiro; fig. 12a,b), indicating an oblique, dextral normal, slip.

\subsubsection{Paleoseismic analysis of Lagoa do Capitão Fault}

An $8.5 \mathrm{~m}$ long trench was open across the main strand of Lagoa do Capitão Fault, about $400 \mathrm{~m}$ east of the lake (fig. 13). The sequence exposed is composed of alternating layers of basaltic pyroclasts and colluvium, overlying a basement of basaltic lava flows: 1 - pyroxene/ olivine rich basalt aa lava flow; 2 - pyroxene rich basalt scoria and lapilli fall layer; 3 - colluvium deposit containing basalt clasts (from 1?) and lapilli (from 2?) in clay matrix; a paleosol developed on this deposit is preserved in places; 4 - discontinuous, strongly weathered, pyroxene rich, basalt lapilli fall layer; 5 - colluvium deposit containing lapilli from 4 in clay matrix; 6 - basalt lapilli fall layer similar to $4 ; 7$ - colluvium containing lapilli from 4 and 6; 8 - fine, pyroxene rich, basalt lapilli layer, containing 
dispersed scoria fragments; the sequence ends with the present soil. All contacts between layers are erosive.

The face of the scarp is cut in lava flows; the same four layers of lapilli are found overlying the lava flows in the up thrown block, but there they are separated by paleosols instead of colluvia (inset B, fig. 13). The topographic position of the colluvial deposits (higher than the depressed region located to the south) and its absence in the up-thrown block confirms that they derive from the fault scarp, although it is not possible to relate them to scarp forming events. The irregular geometry of the colluvial deposits is a conse- quence of erosive episodes that occurred during intervals between deposition of successive lapilli layers and colluvia. Neither the original geometry of colluvial deposits, nor that of pyroclastic layers is preserved.

The trench revealed two main faults, one directly related to the scarp (fault A), and another (fault B), $4 \mathrm{~m}$ to the south, without any significant geomorphic expression (fig. 13). Each fault is composed of numerous slip surfaces, predominantly vertical, sometimes with open voids, presenting small vertical separations that suggest dominant strike slip component associated to down throw to the south.

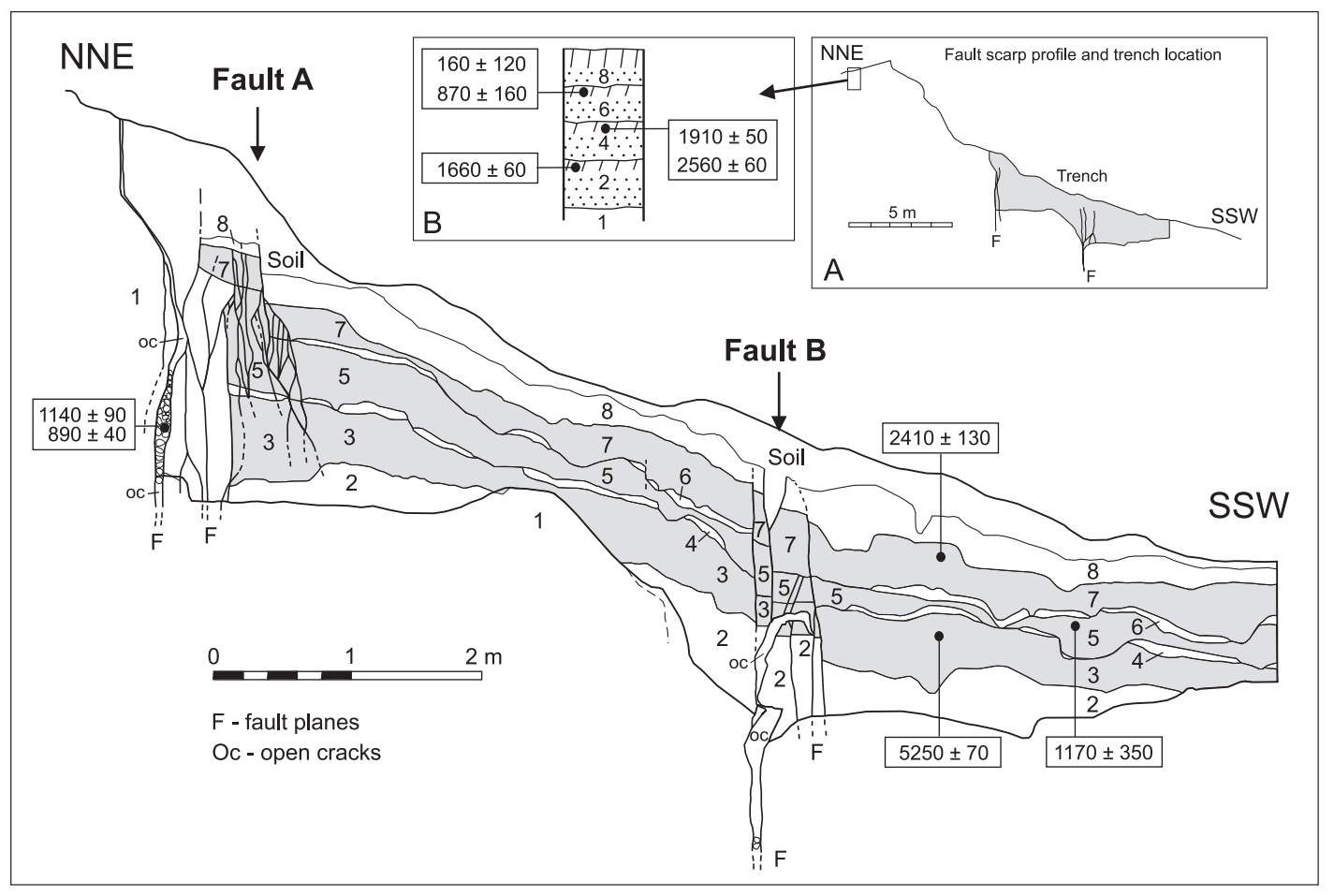

Fig. 13. Simplified and reduced (originally at the $1 / 10$ scale) map of the Lagoa do Capitão trench west wall showing two faults (A and B) associated to LC Fault Zone. The fault scarp, slightly degraded, is related to the northern fault. Stratigraphic sequence is composed of alternating layers of basaltic pyroclastic fall deposits $(2,4,6,8)$ and colluvial wedges $(3,5,7$; in grey), overlying a basement of basaltic lava flows (1); the sequence ends with present topsoil. All contacts are erosional. Inset A: slope profile across the fault and location of trench. Inset B: pyroclastic sequence (2, 4, 6, and 8), separated by dated paleosols and overlying lava flow 1, observed in up-thrown block. Radiocarbon dated deposits indicated (in years BP). 
Samples for radiocarbon analysis were collected from the colluvial layers in the trench and the paleosols separating the lapilli layers in the up-thrown block (fig. 13; table IV). The results revealed radiocarbon/relative age incompatibilities, and no age correlation between colluvia and paleosols separating equivalent lapilli layers; nonetheless, all samples yielded Holocene ages ( 5300-1000 years old; Madeira, 1998), including material fallen into voids in fault A $(1140 \pm$ $\pm 90 \mathrm{BP}$ ), indicating recent surface faulting. This agrees with the observation that the topsoil seems displaced by fault $\mathrm{A}$.

No paleoearthquakes were deduced from the trench because of absence of reliable stratigraphic markers and cumulative vertical separations from the exposed sequence. The pyroclastic and colluvial layers, where they are cut by the fault planes, show variable separations and thicknesses suggesting dominant strike slip component. The vertical separation between correlative lapilli layers exposed in the trench and outcropping on the up-thrown block, is apparent, as the pyroclasts were probably emplaced over a pre-existing scarp cut on lava flows.

\subsection{S. Jorge}

The island of S. Jorge is a $55 \mathrm{~km}$ long fissural active volcano, with a maximum width of $6.7 \mathrm{~km}$, and reaching an altitude of $1053 \mathrm{~m}$ at Pico da Esperança.

The volcanic products in S. Jorge, all basaltic in nature, are divided into three stratigraphic units (Forjaz and Fernandes, 1970, 1975; Forjaz et al., 1970, 1990; Madeira, 1998). The older Topo Volcanic Complex (Tp in fig. 14) constitutes the eastern part of the island. It is a fissural volcanic zone composed of scoria cones and lava flows. Marine erosion already destroyed the northern half of the lava pile and most of the axial cones, creating steep cliffs 400 to $800 \mathrm{~m}$ high. Cones are only preserved in the east tip of $\mathrm{S}$. Jorge. Four published K/Ar ages (Féraud et al., 1980) range from $550 \pm 60 \mathrm{ka}$ in lavas from the base of the pile, at sea level, to $110 \pm 70$ and $140 \pm 50 \mathrm{ka}$ in the higher lava flows. The Rosais Volcanic Complex (Ro in fig. 14) constitutes the basement of the western part of the island and is similar to Topo Volcanic Complex. The scoria cones in the Rosais axial zone are less degraded and its products less weathered than those of Topo suggesting that this unit is younger. No ages are available for this unit and, because younger lavas cover the contact between Rosais and Topo complexes, it is not possible to establish a field relation in order to confirm the assumed stratigraphic relation. The younger unit is Manadas Volcanic Complex (Mn in fig. 14). It is also a fissural volcanic unit, composed of two alignments of Hawaiian/ Strombolian and Surtseyan cones (one along the axis of the island and another diverging from the former towards the south coast) and the related lava flows. Three eruptions occurred in historic times: two on land in 1580 and 1808 and a probable submarine event in 1964 (fig. 14). The Manadas lavas flowed over cliffs cut in Rosais Volcanic Complex creating lava deltas (locally called fajãs). Radiocarbon dates indicate a Holocene age for this unit; ages of 10 prehistoric volcanic events range from $5310 \pm 80$ to $700 \pm 70$ years BP (Madeira et al., 1998b).

Two main normal dextral WNW-ESE fault zones dominate the younger western half of the island: Picos (P) and Pico do Carvão (PC) fault zones (figs. 14 and 15). On the older eastern half, a set of faults with the same direction defines a graben structure; the most important tectonic structure in that region is the Urze-S. João (USJ) Fault which displays a $10 \mathrm{~km}$ long continuous scarp. The two regions are separated by the left lateral normal NNW-SSE Ribeira Seca (RS) Fault represented by a west facing very degraded scarp. The volcanic axis of the island is left laterally offset by at least $3 \mathrm{~km}$, although the fault seems presently inactive. Three other NNW-SSE structures are marked by alignments of scoria cones west of Ribeira Seca Fault.

\subsubsection{Historical seismicity}

The Island of S. Jorge has been struck by two high magnitude earthquakes since settlement: the July 9th, 1757, with an estimated magnitude $M=7.4$ (Machado, 1949) and the January 1st, 1980, $M=7.2$ event (Hirn et al., 


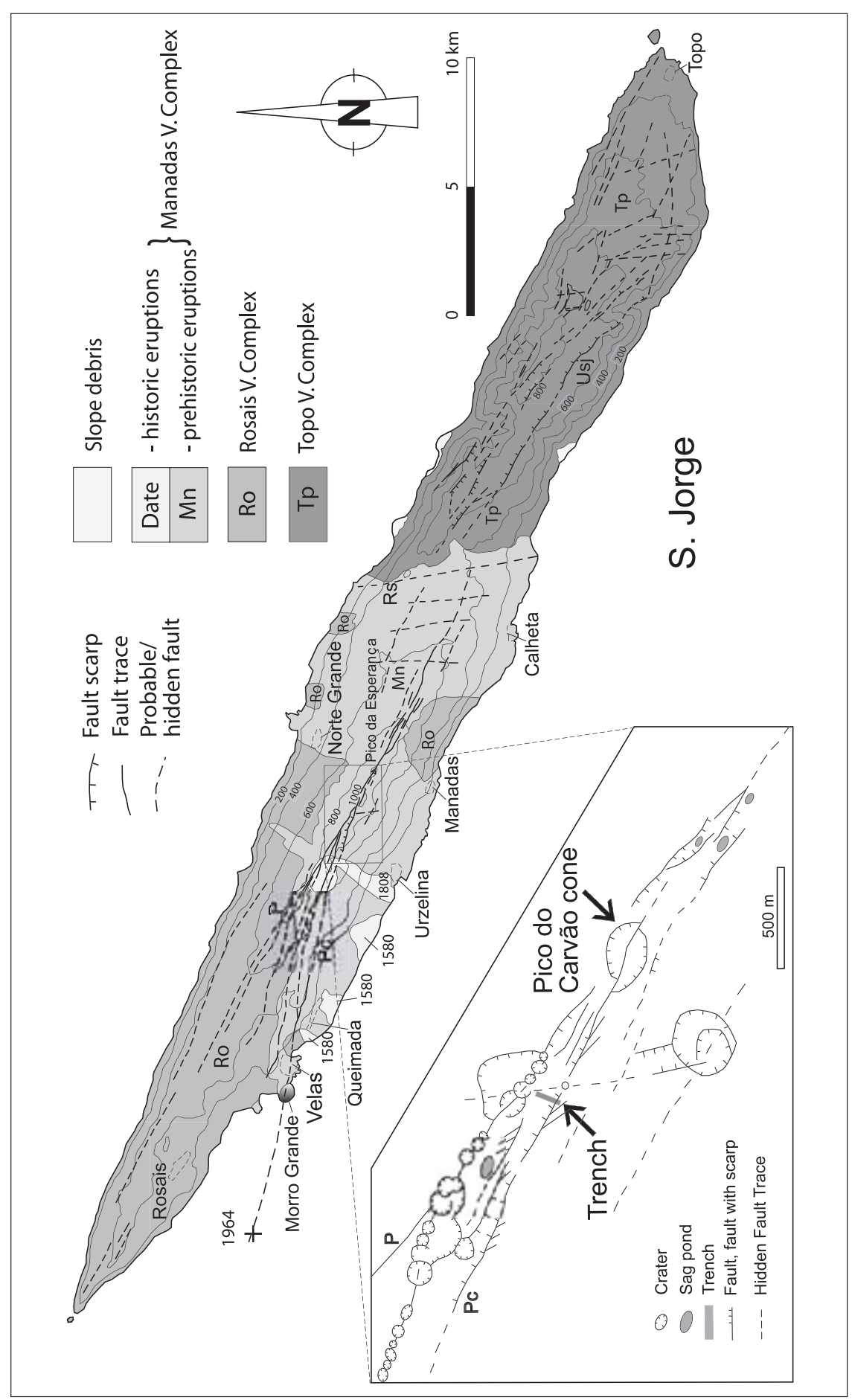

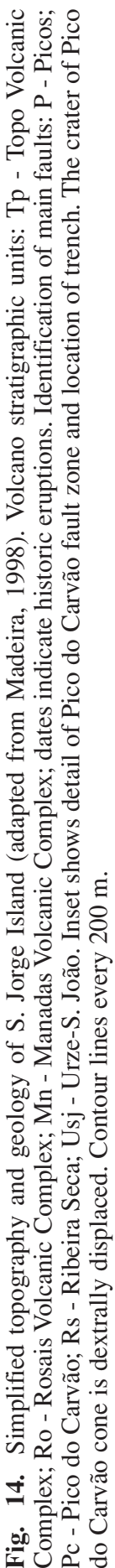




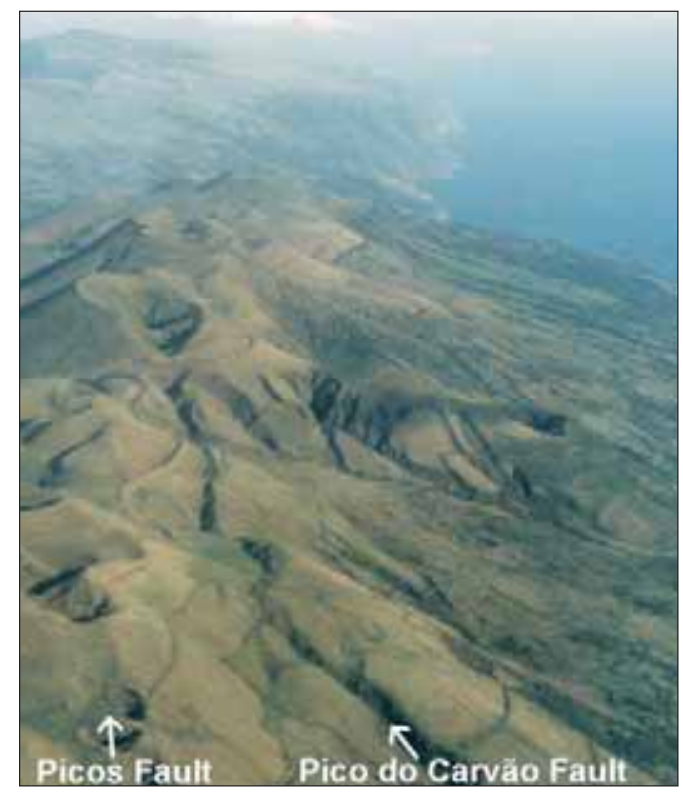

(15)

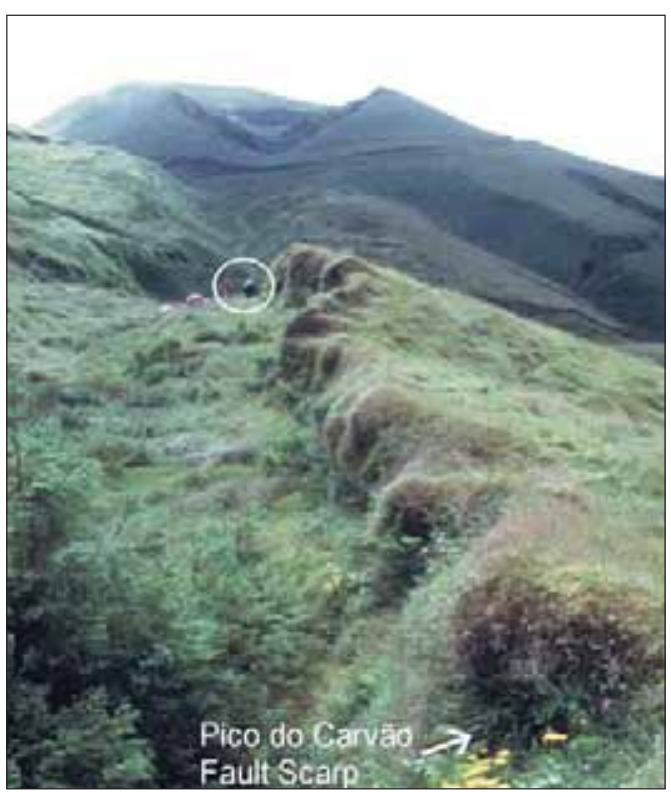

(16)

Fig. 15. Oblique aerial photograph of central part of the island of S. Jorge, above the axial chain of cones, seen from the west. Picos Fault Zone is marked by alignment of cones, craters and scarplets. Pico do Carvão Fault Zone is represented by continuous scarp extending to Pico do Carvão cone where it merges with Picos Fault.

Fig. 16. Pico do Carvão fault scarp seen from the west, with Pico do Carvão scoria cone in background. Persons (encircled) give scale and mark the location of trench.

1980). In both cases the rupture occurred on offshore faults. The 1980 earthquake, with epicentre between S. Jorge, Terceira and Graciosa, produced important destruction on the eastern half of the island and some tens of deaths. The 1757 historic event was even more destructive: all the eastern region of $\mathrm{S}$. Jorge, from the village of Calheta to Topo, was completely destroyed, killing 1000 people in a population of 5000. This earthquake has been related to fault rupture in S. Jorge Channel (between S. Jorge and Pico islands) (Machado, 1949), surface rupture in Pico do Carvão Fault (Ribeiro, 1982), or a fault rupture close to the north coast of the island (Madeira, 1998). The last hypothesis is favoured because a small tsunami, referred in contemporary texts, was observed in Terceira and Graciosa islands, located north of S. Jorge (fig. 2).

\subsubsection{Geometry, kinematics and geomorphic expression of Pico do Carvão Fault}

The Pico do Carvão Fault Zone is composed of three parallel strands, which cross the island of S. Jorge in a N75W direction. It extends for 12 km, from Pico do Carvão cinder cone, where it merges with Pico Fault Zone (figs. 15 and 16), to Morro Grande (Velas) surtseyan cone; to the west it probably extends to the site of the 1964 submarine eruption, adding, at least, $5 \mathrm{~km}$ more to its length. En échelon secondary scarps and a displaced crater indicate that the fault is an oblique, normal dextral, structure.

Holocene volcanism from the Manadas Volcanic Complex (Madeira et al., (1998b) occurred along this structure and its products are locally displaced by the fault. As a result, Pico do Carvão Fault Zone exhibits a well developed and 
continuous geomorphic expression, represented by alignments of volcanic cones and craters and a fault scarp at the eastern sector; the north facing scarp is $1750 \mathrm{~m}$ long and 2.5 to $10 \mathrm{~m}$ high (inset in fig. 14; figs. 15 and 16).

\subsubsection{Paleoseismic analysis of Pico do Carvão Fault}

An $11.5 \mathrm{~m}$ long trench was opened across the Pico do Carvão fault scarp (fig. 17). It revealed a faulted sequence of basalt lapilli fall deposits (layers 1, 2, 3, 4 and 9) with paleosols developed on top, colluvial deposits from the erosion of the fault scarp (layers 4a, 5, 6, 7 and
$8 b)$ and carbonaceous clay sediments interpreted as sag pond deposits (layer 8). The lapilli layers display southward dips, parallel to the slope. The sedimentary deposits related to the fault scarp are gently dipping to the north, or filling the tectonic depression.

Most of the deposits were radiocarbon dated (table IV; Madeira et al, 1998b): layer 2 younger than 2286-1975 cal B.C. (age of the paleosol developed on 1); layer 3 - younger than 248-545 cal A.D. (age of the paleosol developed on 2); layer 4 - younger than 1221-1406 cal A.D. (age of the paleosol developed on 3); layer $4 \mathrm{a}$ - older than 1221-1303 cal A.D. (soil developed on 4a); layer 5 - 1290-1638 cal A.D. (wood fragment in the base of 5); layer 8 -

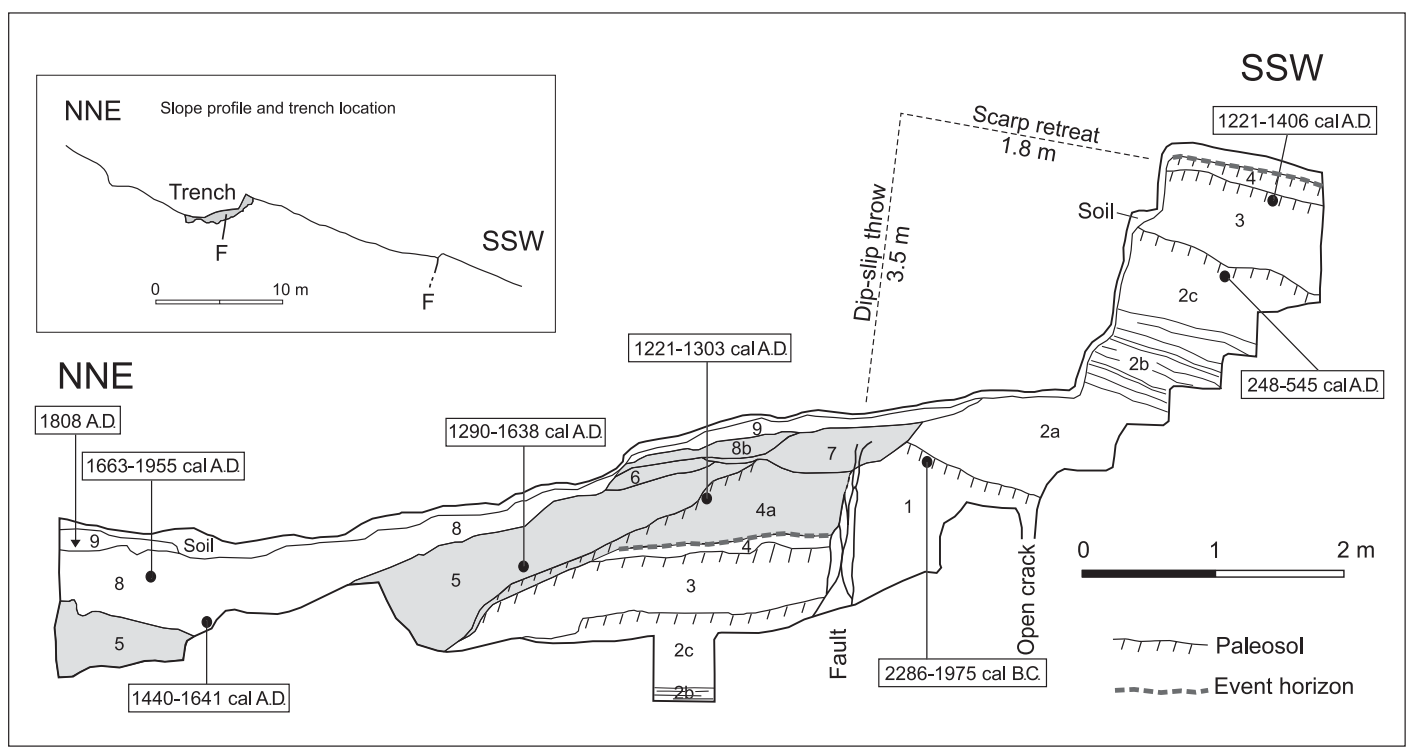

Fig. 17. Simplified and reduced (originally at the $1 / 10$ scale) map of Pico do Carvão trench east wall. The exposed sequence is composed of: 1 - pyroxene rich, basalt lapilli fall layer; 2 - pyroxene rich, basalt scoria and lapilli deposit, including a lower massive coarser zone (2a), a well stratified central deposit (2b), and a upper massive zone, altered by pedogenesis (2c); 3 - sanidine and pyroxene rich basalt lapilli fall deposit; 4 - lithic rich basalt lapilli fall layer; $4 \mathrm{a}$ - colluvial wedge formed by clay supported lapilli, pyroxene and sanidine crystals from layers 3 and 4; 5 - colluvial deposit formed by clay supported lapilli and scoria; 6 - colluvial deposit similar to layer 5; 7 - colluvial deposit, similar to 5, containing intercalated thin layers of fine basaltic ash; 8 - sag pond clayey sediment containing wood fragments, discontinuous peat horizons, and a basaltic fine ash layer (from 1580 eruption), passing laterally to colluvium closer to the fault scarp (8b); 9 - discontinuous basalt lapilli fall layer (probably from 1808 eruption). The sequence ends with a thin soil. Inset shows slope profile across the fault and location of trench. Radiocarbon calibrated dates of deposits indicated ( $2 \sigma$ intervals). 


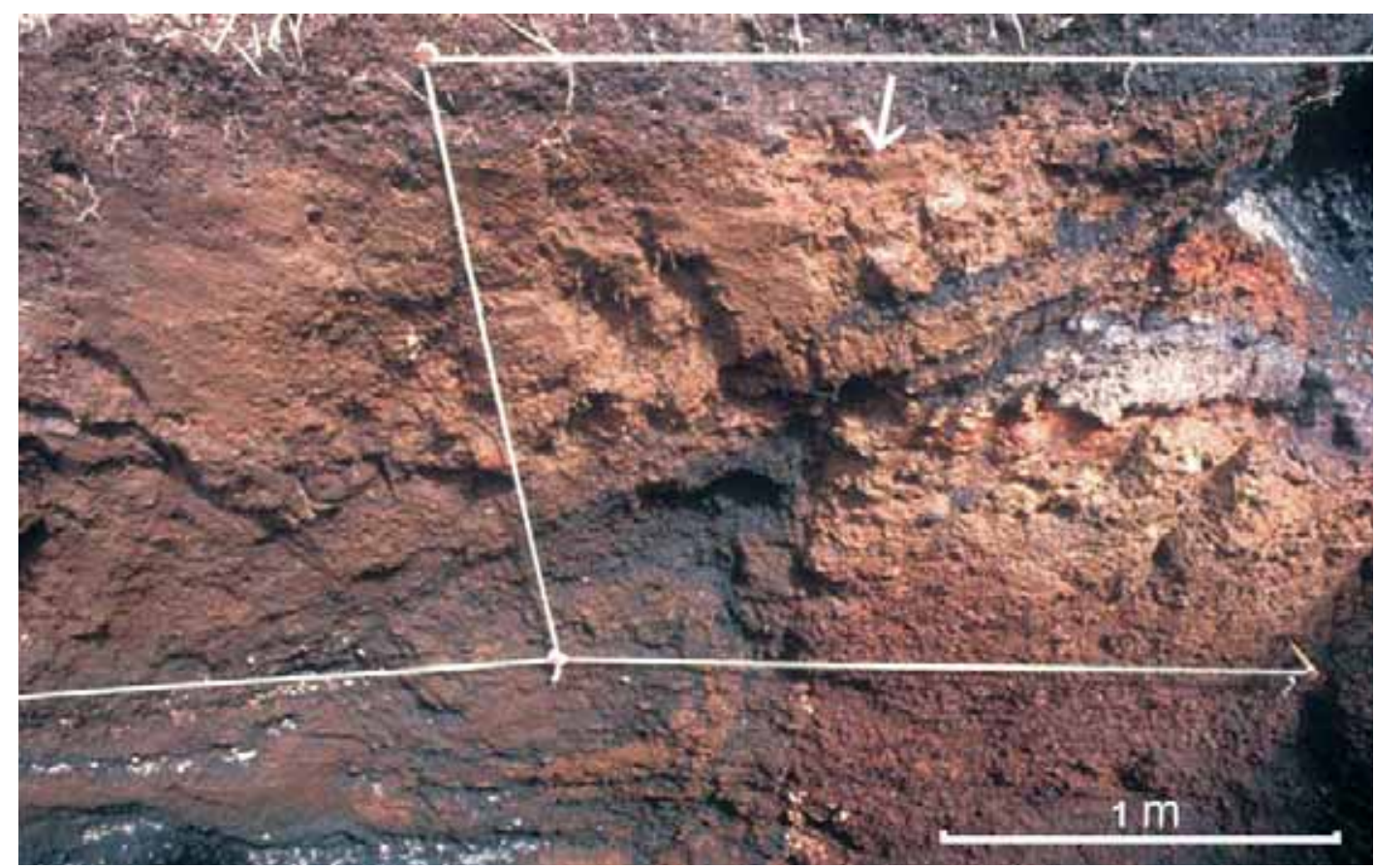

Fig. 18. Photograph of central part of the east wall of Pico do Carvão trench. Fault plane is sharp vertical contact below arrow. To the right (south) of fault plane is lapilli deposit 1 and to the left (north) are deposits 3, 4 and colluvial wedge $4 \mathrm{a}$. Above the fault trace is colluvium 7.

1440-1641 cal A.D. (wood fragment from the base of 8) to 1663-1955 cal A.D. (peat layer some centimetres above an ash layer of the 1580 A.D. eruption); layer 9 - lapilli of the 1808 A.D. eruption.

The fault plane strikes N63-81W, dips $75^{\circ}-85^{\circ}$ to the NNE, and presents an anastomosed geometry (figs. 17 and 18). No striated surfaces were observed. The fault produces $3.5 \mathrm{~m}$ of vertical displacement of levels 2 to 4 , indicating surface rupture following deposition of layer 4, about 750-700 years ago. Since then the fault scarp receded about $1.8 \mathrm{~m}$ but maintains a steep inclination, supported by fast growing vegetation.

Millimetric displacements of thin ash layers in colluvium 7 indicate upward propagation of the fault plane during the 700 to 380 years BP time interval.
There are two possible interpretations for the recent tectonic activity on the trenched Pico do Carvão Fault strand. One is that only one major surface rupture occurred 750-700 years ago, producing the $3.5 \mathrm{~m}$ of displacement observed on stratigraphic references from layers 2, 3 and 4. Another interpretation is that the $3.5 \mathrm{~m}$ separation is the sum of displacements produced by more than one surface rupturing events in the period between $700 \pm 70 \mathrm{BP}$ to $380 \pm 40 \mathrm{BP}$. There is no way of verifying if layers 5 and 6 accumulated different amounts of normal separation because they are only preserved in the downthrown block. However, the propagation of the fault plane to colluvium 7 is indirect evidence that those colluvia may be tectonically displaced (figs. 17 and 18).

Different estimates for the average recurrence interval between seismic events producing sur- 
face displacement derive from the two hypotheses. The first interpretation is that one major earthquake occurred 782-597 years ago, after a time interval of at least 3000 years without surface rupturing events; this is deduced from the fact that levels 2, 3 and 4 show the same amount of normal separation. The second interpretation is that, after 3000 years without surface rupture, more than one event (possibly two, represented by colluvial wedge $4 \mathrm{a}$ and colluvium 6 ?) occurred within an interval of less than 420 years (from 1221-1406 A.D. to 1440-1641 A.D.), producing an accumulated separation of $3.5 \mathrm{~m}$. This may indicate the occurrence of short periods of seismic clustering, as observed in Lomba do Meio trench, separated by longer periods without surface rupture. Recurrence interval between single events or clusters of events is equal or larger than 3000 years.

The slip rate in the trenched strand of the Pico do Carvão Fault, taking into account that $3.5 \mathrm{~m}$ of slip accumulated in an interval of $\sim 3700$ years, is of the order of $1 \mathrm{~mm} /$ year for the normal component of the fault.

\section{Conclusions: neotectonics and paleoseismology}

In this area of the Azores Plateau, fieldwork observations identified a faulting pattern characteristic of three-dimensional strain (Reches, 1983; Reches and Dieterich, 1983), represented by two main fault systems with oblique slip, each composed of two sets dipping in opposite directions.

The fault geometry and kinematics indicate a stress field with the minimum horizontal compressive stress axis $\left(\sigma_{3}\right)$ trending NE-SW. However, permutations between maximum $\left(\sigma_{1}\right)$ and intermediate $\left(\sigma_{2}\right)$ compressive stress axis (NW-SE horizontal, and vertical, respectively), may originate transtensile or tensile regimes (Reches, 1983). This may explain a history of alternating phases of tectonic activity and phases of volcanism, observed in the archipelago since settlement.

In the studied islands, all faults can be considered active (in the sense of Boschi et al., 1996) as they displace volcanic sequences younger than 100 ka (Féraud et al., 1980; Chovelon, 1982).
Long-term slip rates range from tens of millimetre to some centimetres per year (Madeira, 1998) and nearly $70 \%$ of the estimates are in the order of 0.10 to $0.40 \mathrm{~cm} /$ year. Paleoseismic slip rates are in the same order of magnitude (table V).

Average recurrence intervals were estimated in both Lomba do Meio and Pico do Carvão trenches (table V). In Lomba do Meio, surface rupturing events suggest clustering separated by gaps of roughly 500 years. Recurrence interval within cluster is $102 \pm 20$ years. In Pico do Carvão, information is less reliable but also suggests that clustering may occur; the time gap before first paleoearthquake is $\geq 3000$ years, and two earthquakes may have occurred in less than 420 years.

In Lagoa do Capitão the age of deposits filling voids in fault plane A, suggests that the most recent surface rupturing event may have occurred about 1000 years ago, providing a minimum value for the recurrence interval.

Slip per event values, determined in Lomba do Meio trench, vary from $0.15 \mathrm{~m}$ to more than $2 \mathrm{~m}$ (SE1 - > $0.65 \mathrm{~m}$; SE2 - $0.95 \mathrm{~m}$; SE3 - > 2.0 m; SE4 - > $0.60 \mathrm{~m}$; SE5 - > $0.60 \mathrm{~m}$; SE6 $>0.40 \mathrm{~m}$; SE7 - $0.15 \mathrm{~m}$ ). One, or two, surface rupturing events accumulated $3.5 \mathrm{~m}$ of normal slip in Pico do Carvão trench; in the second hypothesis, considering that colluvial wedge $4 \mathrm{a}$ had an original thickness of $1 \mathrm{~m}$ at the fault scarp, the two events may have produced $2 \mathrm{~m}$ and $1.5 \mathrm{~m}$ of slip, respectively.

According to the available parameters (slip rate, recurrence interval and slip per event), the degree of fault activity, in the studied islands, is high to moderate (classes 2 to 4 according to Slemmons, 1982).

\section{Discussion and conclusions: seismic hazard assessment}

Seismic hazard assessment in the Azores is a complex task. One problem is the determination of strike slip component in oblique slip faults; often, in the lack of markers for strike slip, only the dip slip component is detectable, leading to underestimated net slip values. Another complexity is that geologic record 
Table V. Estimated slip rates and recurrence intervals of faults from Faial, Pico and S. Jorge.

\begin{tabular}{|c|c|c|c|c|c|c|c|c|}
\hline \multirow{2}{*}{ Fault / island } & \multicolumn{3}{|c|}{ Separation (m) } & \multirow{2}{*}{$\begin{array}{c}\text { Age of } \\
\text { marker (Ky) }\end{array}$} & \multicolumn{3}{|c|}{ Slip rates (cm/year) } & \multirow{2}{*}{$\begin{array}{l}\text { Average } \\
\text { recurrence } \\
\text { interval } \\
\text { (years) }\end{array}$} \\
\hline & Normal & Strike & Net & & Normal & Strike & Net & \\
\hline $\begin{array}{l}\text { Ribeirinha } \\
\text { Faial }\end{array}$ & 120 & 80 & 144 & $\begin{array}{l}580 \text { or } \\
73-40\end{array}$ & $\begin{array}{c}0.02 \text { or } \\
0.16-0.30\end{array}$ & $\begin{array}{c}0.01 \text { or } \\
0.11-0.20\end{array}$ & $\begin{array}{c}0.03 \text { or } \\
0.20-0.36\end{array}$ & \\
\hline $\begin{array}{l}\text { Lomba Grande } \\
\text { Faial }\end{array}$ & 200 & & & $73-40$ & $0.37-0.50$ & & & \\
\hline $\begin{array}{l}\text { Rocha Vermelha } \\
\text { Faial }\end{array}$ & $\begin{array}{l}150 \\
23\end{array}$ & & & $\begin{array}{l}73-40 \\
50-10 \\
\end{array}$ & $\begin{array}{l}0.21-0.38 \\
0.05-0.23 \\
\end{array}$ & & & \\
\hline $\begin{array}{l}\text { Espalamaca } \\
\text { Faial }\end{array}$ & 145 & & & $73-40$ & $0.20-0.36$ & & & \\
\hline $\begin{array}{l}\text { Flamengos } \\
\text { Faial }\end{array}$ & 115 & & & $73-40$ & $0.16-0.29$ & & & \\
\hline $\begin{array}{l}\text { Lomba do Meio } \\
\text { Faial }\end{array}$ & $\begin{array}{c}50-60 \\
4(*) \\
\end{array}$ & & & $\begin{array}{c}15-10 \\
1.113-0.963 \\
\end{array}$ & $\begin{array}{l}0.33-0.60 \\
0.36-0.42 \\
\end{array}$ & & & 500 \\
\hline $\begin{array}{l}\text { Lomba de Baixo } \\
\text { Faial }\end{array}$ & $30-50$ & & & $15-10$ & $0.2-0.5$ & & & $\sim 500$ \\
\hline $\begin{array}{l}\text { Capelo } \\
\text { Faial }\end{array}$ & 0.49 & & & $\sim 1$ & 0.05 & & & \\
\hline $\begin{array}{l}\text { Lagoa do Capitão } \\
\text { Pico }\end{array}$ & 60 & & & $\begin{array}{l}270-25 \\
\text { or } 10\end{array}$ & $\begin{array}{l}0.02-0.24 \\
\text { or } 0.6\end{array}$ & & & $>1000$ \\
\hline Topo-Pico & 44 & 600 & 602 & $290-210$ & $0.015-0.02$ & $0.20-0.29$ & $0.21-0.29$ & \\
\hline Picos-S. Jorge & $>10$ & & & $5.3-5.6$ & $>0.2$ & & & \\
\hline $\begin{array}{l}\text { Pico do Carvão } \\
\text { S. Jorge }\end{array}$ & $3.5(*)$ & & & 3.7 & 0.1 & & & $\sim 3000$ \\
\hline $\begin{array}{l}\text { Urze-S. João } \\
\text { S. Jorge }\end{array}$ & $>20$ & & & $<100$ & $>0.02$ & & & \\
\hline
\end{tabular}

Separations measured in main volcano-stratigraphic units by cartographic methods, from displaced morphologic markers (Madeira, 1998), or in trenches $(*)$.

does not allow the discrimination between coseismic, post-seismic and aseismic slip; this problem is being currently assessed by GPS monitoring of a network of 60 markers, strategically implanted on the three islands (DISPLAZOR, 2002). An additional difficulty is that the interaction between volcanism and faulting complicates the interpretation of paleo surface ruptures; there is evidence that surface deformation associated to eruptions may concentrate along pre-existing faults, leading to surface displacement events that are difficult to distinguish from those produced by coseismic deformation. Furthermore, the available empirical relations between seismic rupture parameters and magnitude are not adequate for the par- ticular tectonic environment in the Azores Plateau (oceanic crust in a transtensile regime), where lithospheric structure is not well understood, and a thin oceanic crust interacts with magmatism.

Testing the Wells and Coppersmith (1994) equations with rupture parameters of two recent earthquakes shows that the magnitudes obtained do not differ significantly from those assigned by seismology methods. The 1st January 1980 , 6.9 to 7.2 magnitude, earthquake (Hirn et al., 1980; Moreira, 1991) produced a 50-60 km long surface rupture, based on the epicentral distribution of aftershocks (Hirn et al., 1980). Applying the Surface Rupture Length (SRL) to the SRL/M correlation $\left[M_{w}=5.08+1.16 \log (\mathrm{SRL})\right]$ yields 
magnitudes $M_{w}=7.05$ to 7.14 , inside the magnitude interval attributed by the cited authors. Magnitude estimation from Rupture Area (RA) $\left[M_{w}=4.07+0.98 \log (\mathrm{RA})\right]$ has to deal with unknown, and probably variable, schizosphere thickness in the Azores. Hirn et al. (1980) indicate a $14 \mathrm{~km}$ thickness based on the depth distribution of the 1980 aftershocks, Grimison and Chen (1986) consider $10 \mathrm{~km}$, while Luís et al. (1998), based on gravity data, suggest $7 \mathrm{~km}$. Magnitudes estimated from M/RA using the thickness value indicated by Hirn et al. (1980) are in better agreement with those assigned to the 1980 event $\left(M_{w} \sim 6.9\right)$. The same verification was made relatively to the 6.2 magnitude, July 9 , 1998 , event that produced a surface rupture estimated as $8-10 \mathrm{~km}$, based on the epicentral distribution of aftershocks (Vales et al., 2000). Magnitude estimates from SRL range from $M_{w}=6.13$ to 6.24 , while using RA (for a thickness of 14 km) $M_{w}=6.08$ to 6.17 are obtained. Both SRL and RA derived estimates are also significantly close to the assigned magnitude.

Because of its submarine location, Maximum Displacement (MD) is unknown in both earthquakes so $\mathrm{MD} / \mathrm{M}$ correlation cannot be tested. In the lack of a more appropriate equation, it is assumed that estimation of magnitude from slip per event, using equations such as the Wells and Coppersmith's, is the only available for seismic hazard assessment.

The $M_{w}$ values obtained, considering total rupture of the known length of the Espalamaca/ Lomba do Meio/Capelo (19.5 km), Lagoa do Capitão $(30 \mathrm{~km})$, and Pico do Carvão $(17 \mathrm{~km})$ faults and a seismogenic thickness of $14 \mathrm{~km}$ (Hirn et al., 1980), range from $M_{w}=6.5$ to 6.8 and $M_{w}=6.4$ to 6.7 using the M/SRL and $\mathrm{M} / \mathrm{RA}$ relations, respectively.

Higher, less credible, magnitudes are obtained applying the Maximum Displacement (MD) and Moment Magnitude $\left(M_{w}\right)$ regression equation $\left[M_{w}=6.69+0.74 \log (\mathrm{MD})\right]$ (Wells and Coppersmith, 1994). Considering the observed displacements per event in the Lomba do Meio trench $(0.15 \mathrm{~m}->2.0 \mathrm{~m})$, moment magnitudes range from $M_{w}=6.1$ to 6.9. Pico do Carvão trench data suggest either a single, $M_{w}=7.1$, event (producing $3.5 \mathrm{~m}$ of normal slip) or two, $M_{w}=6.9$ and 6.8 , events (generat- ing 2 and $1.5 \mathrm{~m}$ of slip, respectively). Both the MD and SRL values are underestimated, leading to under evaluation of maximum expected magnitudes. MD values, determined in trenches, do not take the strike slip component in account, and may not represent maximum displacements, as they were obtained in a single cross section of the fault. On the other hand, the total length of faults is certainly larger because they extend to offshore regions for which there are no detailed bathymetry.

Furthermore, averaged recurrence intervals do not express seismic behaviour of the faults through time because of suggested clustering of events; this makes it difficult to assess the probability of future earthquakes. However, the high number of active faults in each island is clear evidence for a high seismic potential in the area.

\section{Acknowledgements}

We thank late Prof. José Ávila Martins of Azores University, Dr. Renato Leal, Mayor of Horta, and Dr. Manuel Vargas, director of Serviços de Desenvolvimento Agrário, in Faial, Eng. José Ferreira, director of Secretaria Regional da Habitação e Obras Públicas, and Manuel Paulino Costa, Mayor of Lajes, in Pico, and Eng. Alfredo Alvura and Miss Isabel Jorge, directors of Secretaria Regional da Habitação e Obras Públicas, and Frederico Maciel, Mayor of Velas, in S. Jorge, for considerable logistical support. Fieldwork was financed by SISPOR (PEAM/C/RNT/35/91) and DISPLAZOR (POCTI/32444/CTA/2000) research projects. Editorial Committee of Instituto Geológico e Mineiro kindly authorized the reproduction of photographs in fig. 7. We also acknowledge the contribution of the reviewers and volume editor Daniela Pantosti to significant improvements in the manuscript. This is a contribution from LATTEX- Laboratório de Tectonofísica e Tectónica Experimental research team.

\section{REFERENCES}

Boschi, E., G. Domenico, D. Pantosti, G. Valensise, R. Arrowsmith, P. Basham, R. Bürgmann, A.J. Crone, A. Hull, R.K. McGuire, D. Schwartz, K. Sieh, S.N. 
WARD and R.S. YEATS (1996): New trends in active faulting studies for seismic hazard assessment, Ann. Geofis., 39 (6), 1301-1307.

Buforn, E., A. Udías and M.A. Colombas (1988): Seismicity, source mechanisms and tectonics of the Azores-Gibraltar plate boundary, Tectonophysics, 152, 89-118.

Chovelon, P. (1982): Évolution volcanotectonique des iles de Faial et de Pico, M.Sc. Thesis, Paris-Sud University, Centre d'Orsay, pp. 186.

DISPLAZOR (2002): Tectonic, Volcanic, and Landslide Displacement Monitoring at Faial, Pico, and S. Jorge (Azores) Using GPS, http://mat.fc.ul.pt/eg/displazor.html

FÉraud, G., I. KANEOKA and C.J. AllÈgRe (1980): K-Ar ages and stress pattern in the Azores: geodynamic implications, Earth Planet. Sci. Lett., 46, 275-286.

FoRJAZ, V.H. (1992): Considerações sobre o Risco Vulcânico dos Açores, in 10 Anos Após o Sismo de 1 de Janeiro de 1980, edited by C.S. OliveIRA, A.R.A. LuCAS and J.H. CoRreia Guedes (S.R.H.O.P. Açores and L.N.E.C.), vol. 1, 215-221.

ForJAZ, V.H. and N.S.M. FERNANDES (1970): Folha «B» da ilha de S. Jorge (Acores) da Carta Geológica de Portugal na escala 1:50000, Serviços Geológicos de Portugal, 1 sheet.

ForJAZ, V.H. and N.S.M. FERNANDES (1975): Notícia explicativa das Folhas «A» e «B» da ilha de S. Jorge (Açores) da Carta Geológica de Portugal na escala 1:50000, Serv. Geol. Port., pp. 25.

ForjaZ, V.H. J. MONJARDino and N.S.M. Fernandes (1970): Folha «A» da ilha de S. Jorge (Açores) da Carta Geológica de Portugal na escala 1:50000, Serv. Geol. Port., 1 sheet.

Forjaz, V.H., A. Serralheiro and J.C. Nunes (1990): Carta Vulcanológica dos Açores - Grupo Central na Escala 1:200000, edited by Serviço Regional Protecção Civil dos Açores, Universidade dos Açores and Centro de Vulcanologia INIC, Ponta Delgada, 1 sheet.

Grimison, N.L. and W.P. CHEN (1986): The AzoresGibraltar plate boundary: focal mechanisms, depths of earthquakes and their tectonic implications, J. Geophys. Res., 92, 2029-2047.

GRÜNTHAL, G. (1998): European Macroseismic Scale 1998 (European Seismologic Commission, Luxembourg), 1 st edition.

Hirn, A., H. Haessler, P. Hoang-Trong, P. Wittlinger and L. MENDES Victor (1980): Aftershock sequence of the January 1st, 1980 earthquake and present-day tectonics in the Azores, Geophys. Res. Lett., 7 (7), 501-504.

LAUGhton, A.S. and R.B. Whitmarsh (1974): The AzoresGibraltar plate boundary, in Geodynamics of Iceland and the North Atlantic Area, edited by L. KRISTJANSSON (D. Reidel Publ. Co.), 63-81.

Lourenço, N., J.M. Miranda, J.F. Luis, A. Ribeiro, L.A. Mendes-Victor, J. MAdeira and H.D. NeEDHAM (1998): Morpho-tectonic analysis of the Azores Volcanic Plateau from a new bathymetric compilation of the area, Mar. Geophys. Res., 20 (3), 141-156.

Luís, J.F., J.M. Miranda, A. Galdeano and P. Patriat (1998): Constraints on the structure of the Azores spreading center from gravity, Mar. Geophys. Res., 20 (3), $157-170$
Machado, F. (1949): O terramoto de S. Jorge, em 1757, Açoreana, 4 (4), 311-324.

MACHADO, F. (1966): Anomalias das intensidades do terramoto de S. Miguel (Açores) em 1522, Bol. Mus. Lab Mineral. Geol. Fac. Ciênc. Lisboa, 10 (2), 109-117.

MAdEIRA, J. (1998): Estudos de neotectónica nas ilhas do Faial, Pico e S. Jorge: uma contribuição para o conhecimento geodinâmico da junção tripla dos Açores, Ph.D. Thesis, Lisbon University, pp. 481.

MAdeIRA, J. and A. RiBEIRo (1990): Geodynamic models for the Azores triple junction: a contribution from tectonics, Tectonophysics, 184 (3/4), 405-415.

Madeira, J., A.M. Monge Soares, A. Brum da Silveira and A. SERRALHEIRO (1995): Radiocarbon dating recent volcanic activity on Faial Island, Azores, Radiocarbon, 37 (2), 139-147.

Madeira, J., A. Brum da Silveira and A. Serralheiro (1998a): Efeitos geológicos do sismo do Faial de 9 de Julho de 1998, Protecção Civil (Serviço Nacional de Protecção Civil), 14, 12-20.

Madeira, J., A. Brum da Silveira, A. Serralheiro, A. Monge SoARES and C.F. Rodrigues (1998b): Radiocarbon ages of recent volcanic events from the island of S. Jorge (Azores), Comunicações do IGM, 84 (1), A189-192.

McKenzie, D. (1972): Active tectonics of the Mediterranean region, Geophys. J. R. Astron. Soc., 30 109-185.

Mezcua, J., J. Rueda and J.M. Martínez Solares (1991): Seismicity of the Ibero-Maghrebian region, edited by $\mathrm{J}$. MEZCUA and A. UdíAs (Instituto Geografico Nacional, Madrid), Série Monografia, 8, 17-28.

Miranda, J.M., L.A. Mendes Victor, J.Z. Simões, J.F Luis, L. Matias, H. Shimamura, H. Shiobara, H. Nemoto, H. MochizUKi, A. HiRn and J.C. LÉPINE (1998): Tectonic setting of the Azores Plateau de duced from a OBS survey, Mar. Geophys. Res., 20 (3), 171-182.

MoREIRA, V.S. (1991): Historical seismicity and seismotectonics of the area situated between the Iberian Peninsula, Morocco, Selvagens and Azores islands, in Seismicity, Seismotectonics and Seismic Risk of the Ibero-Maghrebian Region, edited by J. MezcuA and A. UDíAs (Instituto Geografico Nacional, Madrid), Série Monografia, 8, 213-225.

NunES, J.C. (1991): Microssismos e neotectónica: contribuição para o seu estudo nos Açores, M.Sc. Thesis, Azores University, pp. 245.

NuNES, J.C. (1999): A actividade vulcânica na ilha do Pico do Plistocénico superior ao Holocénico: mecanismo eruptivo e hazard vulcânico, Ph.D. Thesis, Azores University, pp. 356.

NunES, J.C., J.L. Alves and V.H. ForJaZ (1992): Sismicidade instrumental dos Açores no período 1980-89: implicações neotectónicas, in 10 Anos Após o Sismo de 1 de Janeiro de 1980, edited by C.S. OLIVEIRA, A.R.A. LuCAS and J.H. Correia Guedes (S.R.H.O.P. dos Açores e L.N.E.C.), vol. 1, 141-160.

PACHECO, J. (2001): Processos associados ao desenvolvimento de erupções vulcânicas hidromagmáticas explosivas na ilha do Faial e sua interpretação numa perspectiva de avaliação do Hazard e minimização do Risco, Ph.D. Thesis, Azores University, pp. 330. 
PeArson, G.W. and M. Stuiver (1993): High-precision bidecadal calibration of the radiocarbon time scale 500-2500 B.C., Radiocarbon, 35 (1), 25-33.

Queiroz, G., J.L. Gaspar, P.D. Cole, J.E. Guest, N Wallenstein, A.M. Duncan and J. Pacheco (1995): Erupções vulcânicas no vale das Furnas (ilha de $\mathrm{S}$ Miguel, Açores) na primeira metade do século XV, Açoreana, 8 (1), 159-165.

RECHES, Z. (1983): Faulting of rocks in three-dimensional strain fields. II: Theoretical analysis, Tectonophysics, 95, 133-156.

RECHES, Z. and J. H. DIETERICH (1983): Faulting of rocks in three-dimensional strain fields. I: Failure of rocks in poliaxial, servo control experiments, Tectonophysics, 95, 111-132.

RIBEIRO, A. (1982): Tectónica de placas: aplicação à sismotectónica e à evolução da fronteira de placas AçoresGibraltar, Geonovas, 1 (4), 87-96.

Serralheiro, A., V.H. Forjaz, C.A. Matos Alves and B. RODRIGUES (1989): Carta Vulcanológica dos Açores Ilha do Faial, edited by Serviço Regional de Protecção Civil, Universidade dos Açores and Centro de Vulcanologia INIC, 4 sheets at 1:15000 scale.

SilveIRA, D. (2002): Caracterização da sismicidade histórica da ilha de S. Miguel com base na reinterpretação de dados de macrossísmica: contribuição para a avaliação do risco sísmico, M.Sc. Thesis, Azores University, pp. 149.

SLEMMONS, D.B. (1982): Determination of the design earthquake magnitude for microzonation, in 3rd International Earthquake Microzonation Conference Proceedings, vol. 1, 119-130.

Stuiver, M. and G.W. Pearson (1986): High-precision calibration of the radiocarbon time scale, A.D. 1950-500 B.C., Radiocarbon, 28 (2B), 805-838.

Stuiver, M. and G.W. PeArson (1993): High-precision bidecadal calibration of the radiocarbon time scale,
A.D. 1950-500 B.C. and 2500-6000 B.C., Radiocarbon, 35 (1), 1-23.

TAZIEFF, H. (1959): L'éruption de 1957-1958 et la tectonique de Faial (Açores), Mem. Serv. Geol. Port., 4, 71-88.

UDIAS, A. (1980): Seismic stresses in the region AzoresGibraltar-Western Mediterranean, Rock Mechanics, 9 (suppl.), 75-84.

Udías, A., A. Lopez Arroyo and J. Mezcua (1976): Seismotectonics of the Azores-Alboran region, Tectonophysics, 31, 259-289.

Udías, A., A.F. Espinoza, J. Mezcua, E. Buforn, R. Vegas, S.P. NishenKo, J.M. MartineZ-Solares and A. LOPEZ-ARROYo (1986): Seismicity and tectonics of the North African-Eurasian plate boundary (AzoresIberia-Tunisia), U.S. Geol. Surv. Open-File Rep., 86626.

Vales, D., L. Matias, F. Carrilho, J. Madeira, I. Morais and L. SEnos (2000): Focal mechanisms and source parameters of earthquake sequence following the 9th July 1998 Faial (Azores) event, in Book of Abstracts and Papers of the XXVII General Assembly of the European Seismological Commission, Lisbon, September 2000, pp. 53.

Wells, D.L. and K.J. Coppersmith (1994): New empirical relationships among magnitude, rupture length, rupture width, rupture area, and surface displacement, Bull. Seismol. Soc. Am., 84 (4), 974-1002.

Weston, F.S. (1963/64): List of recorded volcanic eruptions in the Azores with brief reports, Bol. Mus. Lab. Mineral. Geol. Fac. Ciênc. Lisboa, 10 (1), 3-18.

ZBYSZEWSKI, G. (1963): Les phénomènes volcaniques modernes dans l'archipel des Açores, Comunicações dos Serviços Geológicos de Portugal, 47, pp. 227.

Zbyszewski, G. and O. Veiga Ferreira (1959): Rapport de la deuxième mission géologique sur le volcanisme de l'île de Faial, Mem. Serv. Geol. Port., 4, 29-55. 
